\title{
L-lactate metabolism can occur in normal and cancer prostate cells via the novel mitochondrial L-lactate dehydrogenase
}

\author{
LIDIA DE BARI $^{1 *}$, GABRIELLA CHIEPPA $^{2 *}$, ERSILIA MARRA $^{1}$ and SALVATORE PASSARELLA ${ }^{2}$ \\ ${ }^{1}$ Istituto di Biomembrane e Bioenergetica, Consiglio Nazionale delle Ricerche, Via G. Amendola 165/A, 70126 Bari; \\ ${ }^{2}$ Dipartimento di Scienze per la Salute, Università del Molise, Via F. De Sanctis, 86100 Campobasso, Italy
}

Received June 14, 2010; Accepted August 25, 2010

DOI: 10.3892/ijo_00000815

\begin{abstract}
Both normal (PTN1A) and cancer (PC3) prostate cells produce high levels of L-lactate because of a low energy supply via the citric cycle and oxidative phosphorylation. Since some mammalian mitochondria possess a mitochondrial L-lactate dehydrogenase $(\mathrm{mLDH})$, we investigated whether prostate cells can take up L-lactate and metabolize it in the mitochondria. We report here that externally added L-lactate can enter both normal and cancer cells and mitochondria, as shown by both the oxygen consumption and by the increase in fluorescence of $\mathrm{NAD}(\mathrm{P}) \mathrm{H}$ which occur as a result of L-lactate addition. In both cell types L-lactate enters mitochondria in a carrier-mediated manner, as shown by the inhibition of swelling measurements due to the non-penetrant thiol reagent mersalyl. An L-lactate dehydrogenase exists in mitochondria of both cell types located in the inner compartment, as shown by kinetic investigation and by immunological analysis. The mLDHs proved to differ from the cytosolic enzymes (which themselves differ from one another) as functionally investigated with respect to kinetic features and $\mathrm{pH}$ profile. Normal and cancer cells were found to differ from one another with respect to $\mathrm{mLDH}$ protein level and activity, being the enzyme more highly expressed and of higher activity in PC3 cells. Moreover, the kinetic features and $\mathrm{pH}$ profiles of the $\mathrm{PC} 3 \mathrm{mLDH}$ also differ from those of the PNT1A enzyme, this suggesting the occurrence of separate isoenzymes.
\end{abstract}

\section{Introduction}

Cancer is considered a multi-step, complex genetic disease in which oncogenes and tumour suppressor genes undergo mutations with increase and decrease of their functions, respectively. Because of the genetic background of the

Correspondence to: Dr Salvatore Passarella, Dipartimento di Scienze per la Salute (SpeS), Via De Sanctis, 86100 Campobasso, Italy

E-mail: passarel@unimol.it

${ }^{*}$ Contributed equally

Key words: cancer, prostate cell, mitochondria, L-lactate, L-lactate dehydrogenase disease, the study of cancer has traditionally been focused on the identification and functional characterization of many of these cancer genes. Nonetheless, metabolic anomalies in the form of altered flux through key metabolic pathways are primary hallmarks of many malignant tumours. Unfortunately, at present, understanding of cancer cell metabolism remains still partial and under-investigated, thus preventing for instance development of drugs to directly target such altered metabolic pathways of malignant tumours in a metabolic therapy.

There is an interest in the renaissance, from the early days of the 20th century, of an old-fashioned and rather neglected feature of cancer cells, namely their peculiar aerobic metabolism in which a large amount of L-lactate (L-LAC) is produced. In most cases cancer cells have an increased glucose consumption rate in spite of a low respiration and in order to prevent poisoning themselves, they have a concurrent high rate of L-LAC release when compared to normal tissues (1-3). This may result in an increase in L-LAC concentration inside the tumour itself and in its close vicinity $(4,5)$ which could in turn produce local changes in metabolic activities given that the increased local L-LAC concentration could provide a possible source for cell energy requirements in competition with glucose or other substrates (6). On the other hand it was shown that various biological activities of L-LAC can enhance the malignant behavior of cancer cells. They include the activation of hyaluronan synthesis by tumourassociated fibroblasts and direct enhancement of cellular motility which generates favorable conditions for metastatic spread (7). Thus, L-LAC accumulation not only mirrors but also actively enhances the degree of tumour malignancy; accordingly it was found that the mean L-LAC dehydrogenase (LDH) level in breast carcinoma is two-fold greater than in normal breast tissue (8) and a direct correlation was suggested to exist between ovarian epithelial tumour grade and LDH level (9). Thus the elucidation of the L-LAC metabolism and its impairment in cancer cells is an essential goal to be pursued.

A fundamental change in the overall view of the role of L-LAC in metabolism occurred when it was shown that $\mathrm{O}_{2}$ limitation is not a requirement for net L-LAC formation in normal cells and that L-LAC is an important intermediary in glucose metabolism, a mobile fuel for aerobic metabolism, perhaps a mediator of redox state among various compartments both within and between cells and a signal in gene expression $(10,11)$. A basic revolution in thinking about 
L-LAC is actually occurring since it has been accepted that mitochondria can participate in L-LAC metabolism by virtue of a mitochondrial $\mathrm{LDH}(\mathrm{mLDH})$ shown to exist in a variety of mammalian mitochondria (10) and recently included in the MitoCarta (12) and that hydrogen peroxide production takes place as a result of L-LAC metabolism via the putative L-LAC oxidase (L-LAC-OX) in rat liver mitochondria (13).

These recent findings require a substantial revision of views on cancer L-LAC metabolism. At present L-LAC produced in cancer cells is commonly considered only as a waste product to be exported to the bloodstream $(1-3,14,15)$. However, in light of the recent achievements in L-LAC metabolism there is reason to suspect that L-LAC can be metabolized inside the cells and possibly in the mitochondria. In spite of this, to the best of our knowledge, the metabolism of L-LAC has not yet been investigated in cancer cells. Thus, whether cancer cells can take up L-LAC and whether mitochondrial L-LAC metabolism occurs, activities that would be required for the substance to play a role in cancer cell energy metabolism, remains to be established.

Prostate cells provide a good model for such studies. Indeed both normal (PNT1A) and cancer (PC3) cells produce high levels of L-LAC because the energy supply via the citric cycle and oxidative phosphorylation are reduced due to citrate production and export into the extracellular space and into the cytosol in the case of the normal cells and of cancer cells, in which high fatty acid synthesis occurs (16), respectively. Interestingly glutamine $(17)$ and fatty acids $(18,19)$ have already been reported as energy fuel in prostate cancer cells.

We show here that both normal and cancer prostate cells can take up externally added L-LAC which can enter mitochondria in a carrier-mediated manner; in the inner mitochondrial compartment a novel mLDH exists (different from the cytosolic enzyme) which is highly expressed and very active in cancer cells where it differs functionally from that existing in normal cells. Interestingly cytosolic L-LAC dehydrogenases (cLDHs) of normal and cancer cells proved to differ functionally from one another.

\section{Materials and methods}

Antimycin A, aprotinin, arsenite, bovine serum albumin (BSA), cysteine, dithiothreitol, Na-EDTA, EGTA, carbonyl cyanide p-trifluoromethoxyphenylhydrazone (FCCP), glucose, glucose6-phosphate, HEPES, KOH, L-glutamine, L-lactic acid, bovine heart LDH (EC 1.1.1.27), leupeptin, malic acid, mersalyl, porcine heart malate dehydrogenase (MDH) (EC 1.1.1.37), $\mathrm{NADH}, \mathrm{NAD}^{+}$, oxamate, penicillin/streptomycin, pepstatin, phenylmethane-sulfonyl fluoride, potassium cyanide, pyruvic acid, rotenone, sodium pyruvate (PYR), succinic acid, Tris, Triton X-100 and Tween-20, were from Sigma-Aldrich Chemie (Steinheim, Germany); skimmed milk powder and ouabain were from Fluka (Mallinckrodt, Buchs, Switzerland). Sucrose was from Baker (Deventer, The Netherlands). All chemicals were of the purest grade available and were used as Tris salts at $\mathrm{pH}$ 7.0-7.4. Rotenone, antimycin A and FCCP were dissolved in ethanol. Fetal bovine serum and RPMI-1640 were from BioSpa (Milan, Italy). Both primary goat polyclonal anti-LDH, goat polyclonal anti-ß-tubulin (ß-TUB), rabbit polyclonal anticytochrome c oxidase subunit IV (COX IV) and secondary anti-goat and anti-rabbit horseradish peroxidase-conjugated sera were from Abcam Plc. (Cambridge, UK).

Cell cultures. PNT1A cells (a human prostate normal cell line established by immortalization of normal adult prostate epithelial cells) and PC3 cells (a human prostate carcinoma cell line derived from a bone metastasis) were obtained from the European Collection of Cell Cultures (ECACC Salisbury, UK). PNT1A cells were maintained at $37^{\circ} \mathrm{C}$ in the presence of $5 \% \mathrm{CO}_{2}$ in RPMI-1640 supplemented with $10 \%$ inactivated fetal bovine serum, $2 \mathrm{mM}$ glutamine, $100 \mathrm{U} / \mathrm{ml}$ of penicillin and $100 \mu \mathrm{g} / \mathrm{ml}$ of streptomycin. PC3 cells were maintained as for PNT1A cells with the addition of $1 \mathrm{mM}$ PYR.

Cell suspension, homogenate and mitochondria preparations. Before each experiment, the culture medium was removed and the plated PNT1A or PC3 cells were washed with phosphate-buffered saline (PBS) medium containing $138 \mathrm{mM} \mathrm{NaCl}, 2.7 \mathrm{mM} \mathrm{KCl}, 8 \mathrm{mM} \mathrm{Na} \mathrm{HPO}_{4}, 15 \mathrm{mM}$ $\mathrm{KH}_{2} \mathrm{PO}_{4}, \mathrm{pH} 7.4$, and then collected by gentle scraping into a $1 \mathrm{ml}$ of PBS medium.

Cell suspension was obtained by centrifuging collected cells at $3000 \mathrm{rpm}$ for $2 \mathrm{~min}$ and suspending the pellet in the same volume of PBS medium ( $\mathrm{pH} 7.4)$. Cell membrane integrity was assayed by trypan blue exclusion assay (20). The final cell suspension routinely contained $85-95 \%$ intact cells. Cell homogenates from a cell suspension were obtained by 30 gentle strokes with a Dounce Potter homogenizer at room temperature. Rupture of cell membranes was assayed by trypan blue exclusion assay (20). Mitochondria were isolated from cell homogenates as in Pallotti and Lenaz (21) with minor modification. The cell homogenate was centrifuged at $1500 \mathrm{x} \mathrm{g}$ for $10 \mathrm{~min}$. The pellet was re-suspended and homogenised by 20 strokes with a Dounce homogenizer and then centrifuged at $1500 \mathrm{x}$ g for $10 \mathrm{~min}$. The combined supernatants were centrifuged at $1500 \mathrm{x}$ g for $5 \mathrm{~min}$. The supernatant obtained was centrifuged at $17000 \mathrm{x}$ g for $11 \mathrm{~min}$. The pellet, i.e. the mitochondrial fraction, was suspended in standard medium consisting of $0.25 \mathrm{M}$ sucrose, $10 \mathrm{mM} \mathrm{KCl}$, $1.5 \mathrm{mM} \mathrm{MgCl}_{2}, 1 \mathrm{mM}$ Na-EDTA, and $20 \mathrm{mM}$ HEPES-KOH ( $\mathrm{pH} 7.4)$. Cytosolic fractions were obtained by centrifuging $(105,000 \mathrm{x} \mathrm{g}$ for $60 \mathrm{~min})$ the supernatant obtained during mitochondria isolation. All the operations were made on ice and the centrifugations at $4^{\circ} \mathrm{C}$. Mitochondria isolated from cells or present in cell homogenates were checked for their intactness by measuring the activities of adenylate kinase (ADK) and glutamate dehydrogenase (GDH) (22) which are marker enzymes of the mitochondrial intermembrane space and matrix, respectively, in the supernatant obtained by centrifuging either the mitochondrial suspension or the cell homogenate. Glucose-6-phosphate dehydrogenase (E.C. 1.1.1.49), a cytosolic marker, was assayed as described (23) in both mitochondrial and cytosolic fractions. Mitochondrial and cytosolic protein content was determined by the Lowry method (24) with bovine serum albumin (BSA) used as a standard.

Polarographic measurements. Oxygen consumption was measured polarographically (25) using a Hansatech oxygraph with a Clark electrode. Either cell suspensions $\left(10^{7}\right.$ cells $)$ or cell homogenates ( $2 \mathrm{mg}$ protein) were incubated in a 
A

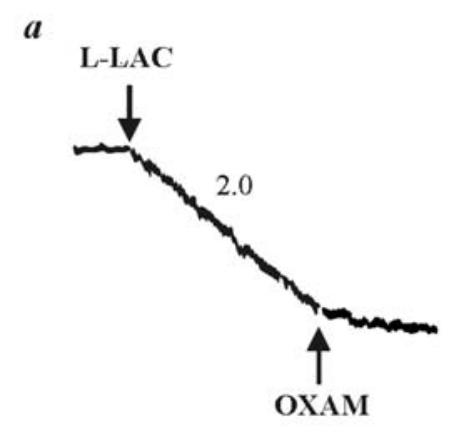

B

a

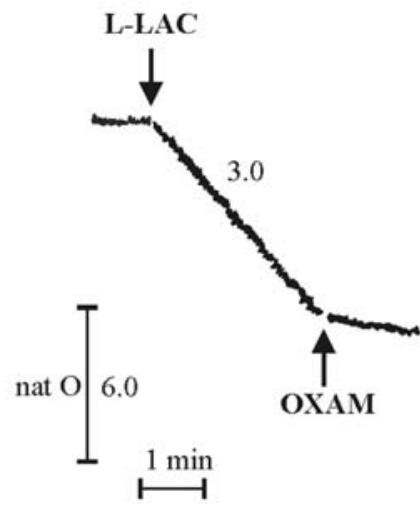

b

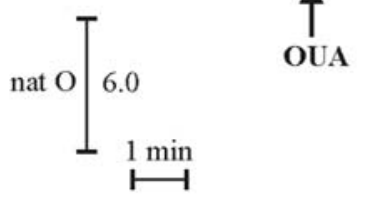
PC3

b

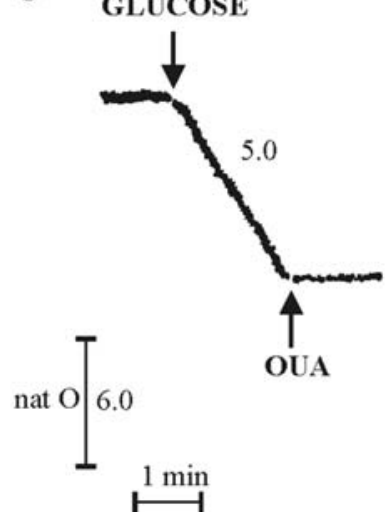

Figure 1. Oxygen uptake by both PNT1A and PC3 cells added with either L-lactate or glucose. Either PNT1A (A) or PC3 (B) cells $\left(10^{7}\right.$ cells each) were incubated in PBS (final volume $0.5 \mathrm{ml}$ ) medium at $25^{\circ} \mathrm{C}$ and oxygen uptake was measured as a function of time. At the arrows the following addition were made: L-lactate (L-LAC, $5 \mathrm{mM}$ ), oxamate (OXAM, $10 \mathrm{mM}$ ), glucose $(10 \mathrm{mM})$, ouabain (OUA, $1 \mu \mathrm{M})$. Numbers along curves are rates of oxygen consumption expressed as natom $\mathrm{O} \times \mathrm{min}^{-1} \mathrm{x} 10^{7}$ cells.

thermostated $\left(25^{\circ} \mathrm{C}\right)$ water-jacketed glass vessel containing PBS (final volume $0.5 \mathrm{ml}$ ) medium. Since the incubation chamber required continuous stirring to allow oxygen to diffuse freely, the design included a magnetic stirring system. The rate of oxygen uptake was measured with the appropriate software from the tangent to the initial part of the progress curve and expressed as natom $\mathrm{O} \times \mathrm{min}^{-1} \times 10^{7}$ cells or natom $\mathrm{O} \times \mathrm{min}^{-1} \mathrm{x} \mathrm{mg}^{-1}$ cell protein. The sensitivity of the instrument was set so as allow rates of oxygen consumption as low as 0.2 natom $\mathrm{O} \mathrm{min} \mathrm{m}^{-1} \mathrm{xg}^{-1}$ protein to be measured.

Fluorimetric assays of the redox state of pyridine nucleotides. Changes in the redox state of pyridine nucleotides were monitored fluorimetrically, using a Perkin-Elmer (Beaconsfield, UK) LS50B spectrofluorimeter set at excitation and emission wavelengths equal to 334 and $456 \mathrm{~nm}$, respectively. Uptake of L-LAC was monitored as described (25). Either PNT1A or PC3 cell suspension (1 mg of protein each) was incubated in $2 \mathrm{ml}$ of PBS medium in the presence of FCCP $(1 \mu \mathrm{M})$ followed by addition of rotenone (ROT, 2 $\mu \mathrm{g})$. $\mathrm{NAD}(\mathrm{P})^{+}$reduction was observed as an increase in fluorescence, and the rate of reaction was calculated as the tangent to the initial part of the progress curve and expressed as nmol $\mathrm{NAD}(\mathrm{P})^{+}$reduced $\mathrm{x} \mathrm{min}^{-1} \mathrm{x} \mathrm{mg}^{-1}$ protein. The $\mathrm{NAD}(\mathrm{P}) \mathrm{H}$ fluorescence was calibrated as described (26).

Swelling experiments. Mitochondrial swelling was monitored photometrically (25) at a wavelength of $546 \mathrm{~nm}$. Mitochondria from PNT1A (PNT1A-M) or from PC3 (PC3-M) $(0.1 \mathrm{mg}$ protein each) were rapidly added to isotonic solutions of ammonium salts, the $\mathrm{pH}$ values of which were adjusted to 7.4, and the decrease in absorbance was recorded.

Enzymatic assays. Assay of LDH was performed photometrically at $25^{\circ} \mathrm{C}$ by means of a Jasco (Tokyo, Japan) V570 spectrophotometer at a wavelength of $334 \mathrm{~nm}$, as described (25), by following the absorbance changes reflecting either $\mathrm{NADH}$ oxidation or $\mathrm{NAD}^{+}$reduction resulting from PYR or L-LAC addition, respectively, as a function of time. For the assays, either Triton X-100 (TX-100) solubilised mitochondria or the cytosolic fractions from either PNT1A or PC3 cells $(0.02 \mathrm{mg}$ of protein each), were incubated in $2 \mathrm{ml}$ of standard medium with $0.2 \mathrm{mM} \mathrm{NADH}$ or $1 \mathrm{mM} \mathrm{NAD}^{+}$, in the presence of ROT $(2 \mu \mathrm{g})$ to avoid NADH oxidation by complex I, and the appropriate substrate was then added to start the reaction. Rates were obtained as the tangent to the initial part of the progress curves and expressed as $\mathrm{nmol} / \mu \mathrm{mol}$

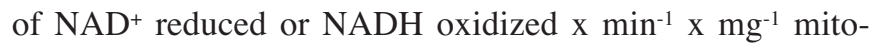
chondrial or cytosolic protein $\left(\varepsilon_{334 \mathrm{~mm}}=6.22 \mathrm{mM}^{-1} \mathrm{x} \mathrm{cm}^{-1}\right)$.

Immunoblot analysis. Immunoblot analysis was performed on either mitochondrial or cytosolic proteins by using antibodies against LDH, COX IV and B-TUB. Antibodies recognizing COX IV and $\beta$-TUB were used as markers of mitochondria and cytosol, respectively. Either isolated mitochondria or cytosolic fractions were added to a medium consisting of $500 \mathrm{mM} \mathrm{NaCl}, 50 \mathrm{mM}$ Tris/HCl $(\mathrm{pH} \mathrm{7.5)}$, $1 \mathrm{mM}$ EGTA, $1 \mathrm{mM}$ Na-EDTA, $0.5 \mathrm{mM}$ dithiothreitol, $2 \mathrm{mM}$ phenylmethanesulphonyl fluoride, $10 \mu \mathrm{g} / \mathrm{ml}$ aprotinin, $10 \mu \mathrm{g} / \mathrm{ml}$ leupeptin, $10 \mu \mathrm{g} / \mathrm{ml}$ pepstatin in the presence of $1 \%$ Triton X-100, used to solubilise mitochondria as well as any cell vesicles formed in the isolation of mitochondria. Protein content was determined using the Bradford reagent (Bio-Rad Laboratories, Hercules, CA, USA), with BSA as a standard. Solubilised proteins $(20 \mu \mathrm{g})$ were subjected to electrophoresis on $12 \%$ SDS/polyacrylamide gels (27). Following electrophoresis, protein blots were transferred to a poly(vinylidenedifluoride) membrane. The membrane was blocked

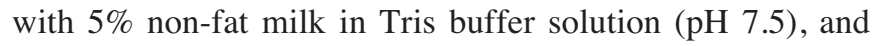
incubated overnight with the corresponding primary antibodies at $4^{\circ} \mathrm{C}$. After washing three times with Tris buffer solution ( $\mathrm{pH} 7.5)$ plus Tween-20 (0.3\%), the membrane was incubated at room temperature for $1 \mathrm{~h}$ with horseradish peroxidase-conjugated secondary antibody. The detected protein signals were visualized with enhanced chemiluminescence Western blot reagents (Amersham, ECL, Little Chalfont, UK). Relative absorbances and areas of bands were quantified using a GS-700 Imaging Densitometer implemented with Molecular Analyst software (Bio-Rad Laboratories).

Statistical analysis and computing. Data are reported as the mean \pm standard deviation (S.D.). Statistical analysis was 
B
A

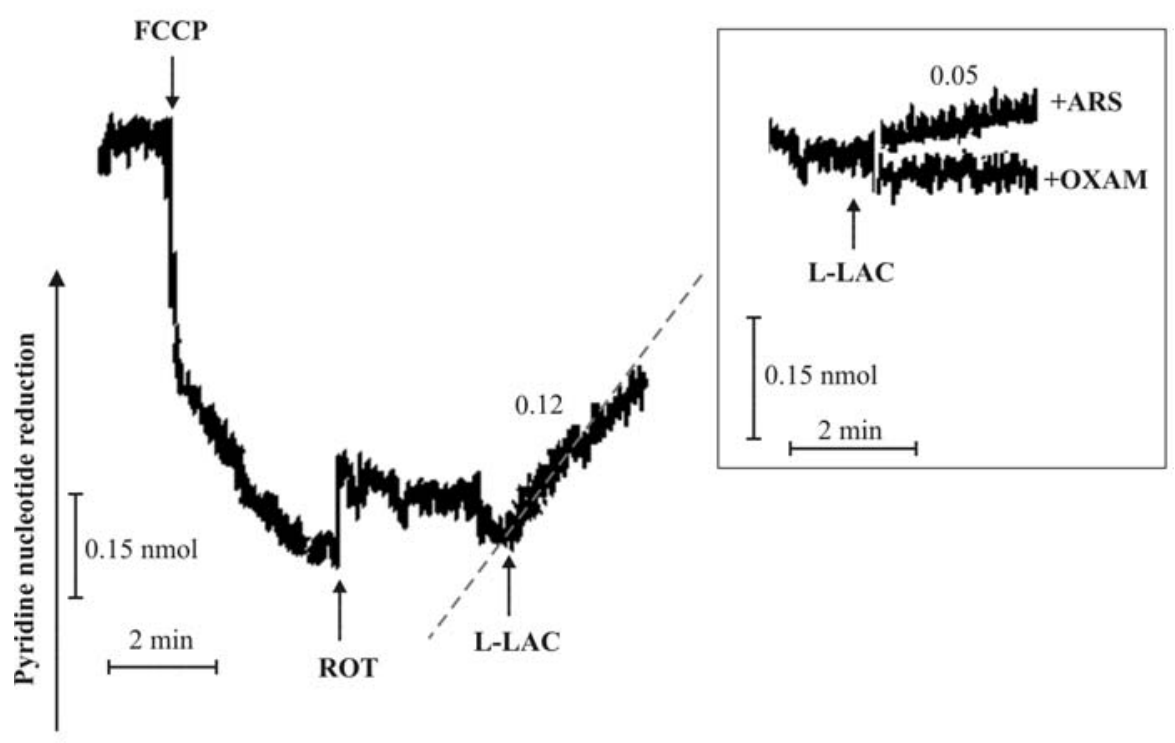

PNT1A
PC3

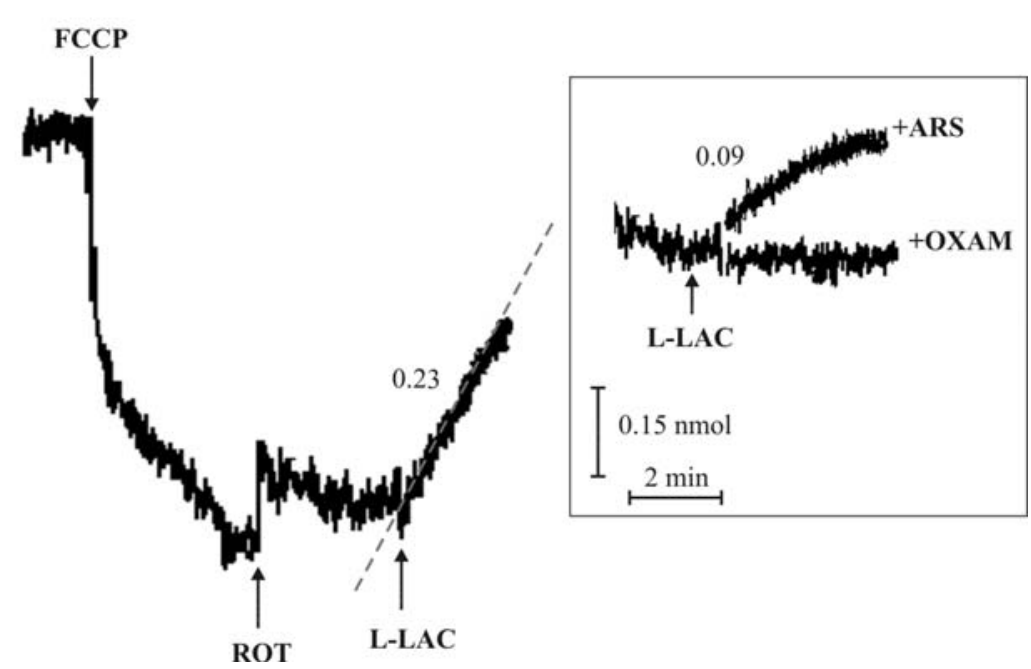

Figure 2. Fluorimetric investigation of the redox state of the pyridine nucleotides caused by L-LAC addition to either PNT1A or PC3 cells. Either PNT1A (A) or PC3 (B) cells (1 mg cell protein each) were incubated at $25^{\circ} \mathrm{C}$ in $2 \mathrm{ml}$ PBS medium in the absence or presence of arsenite (+ARS, $\left.5 \mathrm{mM}\right)$ or oxamate $(+\mathrm{OXAM}, 10 \mathrm{mM})$ and reduction of pyridine nucleotides was followed fluorimetrically $\left(\lambda_{\mathrm{exc}}=334 \mathrm{~nm} ; \lambda_{\mathrm{em}}=456 \mathrm{~nm}\right)$ as a function of time. At the arrows the following additions were made: FCCP $(1 \mu \mathrm{M})$, rotenone (ROT, $2 \mu \mathrm{g}$ ), L-lactate (L-LAC, $5 \mathrm{mM}$ ). Numbers along curves are rates of fluorescence increase measured as the tangent to the initial part of the progress curve and expressed as nmol of intramitochondrial $\mathrm{NAD}(\mathrm{P})^{+}$reduced $\mathrm{x} \mathrm{min}^{-1} \mathrm{x} \mathrm{mg}^{-1} \mathrm{of} \mathrm{protein.}$

performed by the Student's $t$ test. Experimental plots were obtained using Grafit software (Erithacus).

\section{Results}

Externally added L-lactate can enter both prostate cells and isolated mitochondria. In order to gain insight into the LLAC metabolism in prostate cells, an initial set of experiments was carried out to determine whether externally added L-LAC can enter either PNT1A or PC3 cells. This was investigated first by checking whether addition of L-LAC to cells results in oxygen consumption (Fig. 1). As a result of L-LAC ( $5 \mathrm{mM}$ ) addition to either PNT1A or PC3 cells oxygen consumption was found to occur at a rate of 2.0 and 3.0 natom $\mathrm{O} \times \mathrm{min}^{-1} \times 10^{7}$ cells, respectively, in a manner inhibited by either $10 \mathrm{mM}$ oxamate (OXAM), an inhibitor of LDH (28)
(Fig. 1Aa, Ba), or ROT (2 $\mu \mathrm{g})$, an inhibitor of electron flow in respiratory complex I (not shown). In three experiments carried out with different cell preparations the rates of L-LAC oxidation were $1.9 \pm 0.1$ and $3.0 \pm 0.6$ natom $\mathrm{O} \times \mathrm{min}^{-1} \times 10^{7}$ PNT1A or PC3 cells, respectively. In the same experiment, to ascertain whether cells were intact, use was made of glucose $(10 \mathrm{mM})$ as a respiratory substrate either in the absence or presence of ouabain (OUA, $1 \mu \mathrm{M}$ ), which can prevent glucose transport into the cells by blocking the $\mathrm{Na}^{+}-\mathrm{K}^{+}$ pump which drives glucose uptake (29). Glucose oxidation (2.0 and 5.0 natom $\mathrm{O} \times \mathrm{min}^{-1} \times 10^{7}$ PNT1A and PC3 cells, respectively) was completely abolished by OUA in both cases this showing that the cells were intact.

The results in Fig. 1 show that intact prostate cells can take up externally added L-LAC and metabolise it in reaction/s in which $\mathrm{NAD}^{+}$is involved. Both to confirm such a conclusion 
PNT1A-M

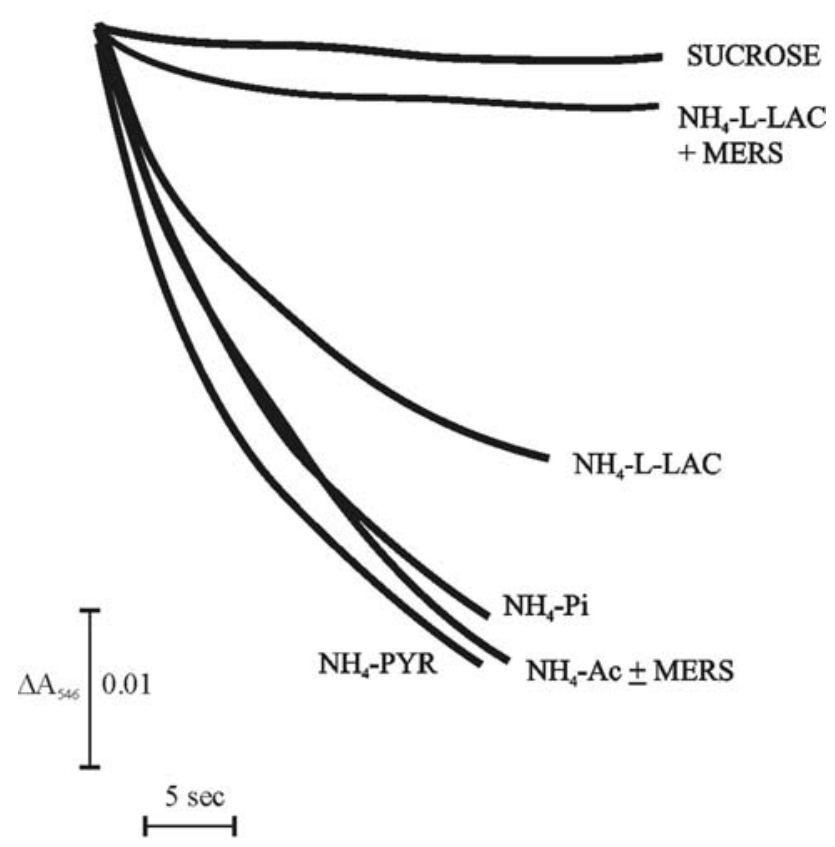

PC3-M

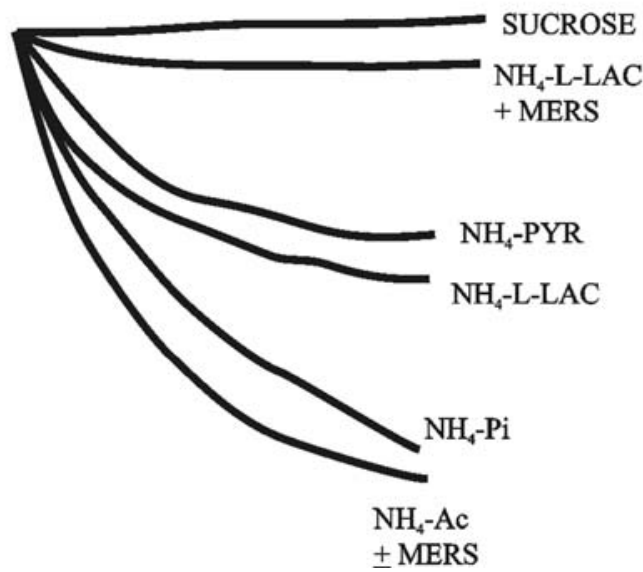

Figure 3. Swelling in ammonium L-lactate solution of mitochondria isolated from either PNT1A or PC3 cells. Either PNT1A-M or PC3-M $(0.1 \mathrm{mg}$ protein each) were added to ammonium acetate $\left(\mathrm{NH}_{4}-\mathrm{Ac}\right)$, ammonium phosphate $\left(\mathrm{NH}_{4}-\mathrm{Pi}\right)$, ammonium L-lactate $\left(\mathrm{NH}_{4}\right.$-L-LAC), ammonium pyruvate $\left(\mathrm{NH}_{4}-\mathrm{PYR}\right)(0.1 \mathrm{M}$ each) or $0.25 \mathrm{M}$ sucrose. Where indicated mersalyl (MERS, $200 \mathrm{nmol} / \mathrm{mg}$ mitochondrial protein) was present in either $\mathrm{NH}_{4}-\mathrm{L}$ LAC or $\mathrm{NH}_{4}$-Ac mitochondrial suspension. Mitochondrial swelling was monitored at the wavelength of $546 \mathrm{~nm}$ as described in Materials and methods.

and to ascertain how L-LAC metabolism occurs, we used a procedure in which prostate cell intrinsic fluorescence was monitored as a function of time, using a wavelength pair designed to monitor the cellular NAD(P)H level (Fig. 2). In a typical experiment, both prostate cell suspensions were treated with the uncoupler FCCP $(1 \mu \mathrm{M})$ which caused the oxidation of the intramitochondrial $\mathrm{NAD}(\mathrm{P}) \mathrm{H}$, and when the fluorescence remained constant ( 3 min later), with ROT (2 $\mu \mathrm{g})$, used to prevent the mitochondrial oxidation of the
$\mathrm{NAD}(\mathrm{P}) \mathrm{H}$ newly formed in the mitochondrial matrix from externally added substrates. Following ROT addition, a small increase in $\mathrm{NAD}(\mathrm{P}) \mathrm{H}$ fluorescence was found likely arising from oxidation of $\mathrm{NAD}^{+}$-linked endogenous substrates. As a result of the addition of $5 \mathrm{mM} \mathrm{L-LAC}$, an increase in fluorescence occurred in both PNT1A and PC 3 cells at a rate of 0.12 and $0.23 \mathrm{nmol} \mathrm{NAD}(\mathrm{P})^{+}$reduced $\mathrm{x} \mathrm{min}{ }^{-1} \mathrm{x} \mathrm{mg}^{-1}$ cell protein, respectively (Fig. $2 \mathrm{~A}, \mathrm{~B})$. In three experiments carried out with different cell preparations the rates were

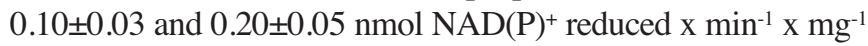
PNT1A and PC3 cell protein, respectively, different as judged by a statistical analysis carried out using the Student's t-test $(\mathrm{p}<0.05)$. This confirms that L-LAC can enter both PNT1A and PC3 cells where it is metabolised in a NAD ${ }^{+}$linked reaction/s.

One possible explanation of the fluorescence increase is that the imported L-LAC can be oxidized to PYR in the cytoplasm via cLDH and then PYR can enter mitochondria to be metabolized via pyruvate dehydrogenase (PDH) with intramitochondrial $\mathrm{NAD}^{+}$reduction. On the other hand, since a mitochondrial LDH exists in a variety of mitochondria $(10,12)$ there is the possibility that L-LAC itself is taken up by mitochondria and oxidized via a putative prostate $\mathrm{mLDH}$ with further oxidation of the newly synthesised PYR via PDH.

The results in Fig. 2 are consistent with both these mechanisms and to distinguish between them we used OXAM and arsenite (ARS) specific inhibitors of LDH and PDH, respectively. In both PNT1A and PC3 cells no fluorescence increase occurred when L-LAC was added in the presence of OXAM $(10 \mathrm{mM})$, this showing the crucial role of LDH in the formation of $\mathrm{NAD}(\mathrm{P}) \mathrm{H}$ (insets to Fig. 2). In a parallel experiment, the addition of ARS $(5 \mathrm{mM})$, which can enter both cells and mitochondria and inhibit PDH (30), decreased the rate of $\mathrm{NAD}(\mathrm{P}) \mathrm{H}$ formation by $\sim 50 \%$ showing that $\mathrm{NAD}(\mathrm{P}) \mathrm{H}$ formation is partially independent of $\mathrm{PDH}$ (insets to Fig 2). PYR (1 mM) itself failed to cause increase in $\mathrm{NAD}(\mathrm{P}) \mathrm{H}$ fluorescence when added to either cell suspension under the same experimental conditions (data not shown), strongly suggesting that the fluorescence increase is due to further oxidation of PYR newly synthesised from L-LAC, via the PDH complex and not to uptake and oxidation of the pyruvate newly synthesised in the cytoplasm from L-LAC. In a control experiment we found that no change of fluorescence takes place in the absence of FCCP, this excluding the possibility that an increase in NADH level had occurred in the cytoplasm by the cLDH reaction. The results of the above experiments require that L-LAC is taken up by mitochondria and that mitochondria contain an $\mathrm{mLDH}$.

To gain insight into the mechanism by which mitochondria from both PNT1A (PNT1A-M) and PC3 (PC3-M) cells can take up externally added L-LAC, mitochondrial swelling in $0.1 \mathrm{M}$ ammonium L-LAC $\left(\mathrm{NH}_{4}\right.$-L-LAC) solution was monitored as absorbance decrease at $546 \mathrm{~nm}$ (Materials and methods). Swelling in an isotonic solution of the ammonium salt of a penetrant anion is characteristic of mitochondria (31). The decrease of absorbance of the prostate mitochondria suspensions in $\mathrm{NH}_{4}$-L-LAC (Fig. 3) shows that they can take up L-LAC and that this occurs in a proton-compensated manner. Both the rate and the amplitude of swelling were lower than that which occurred in $0.1 \mathrm{M}$ ammonium acetate 


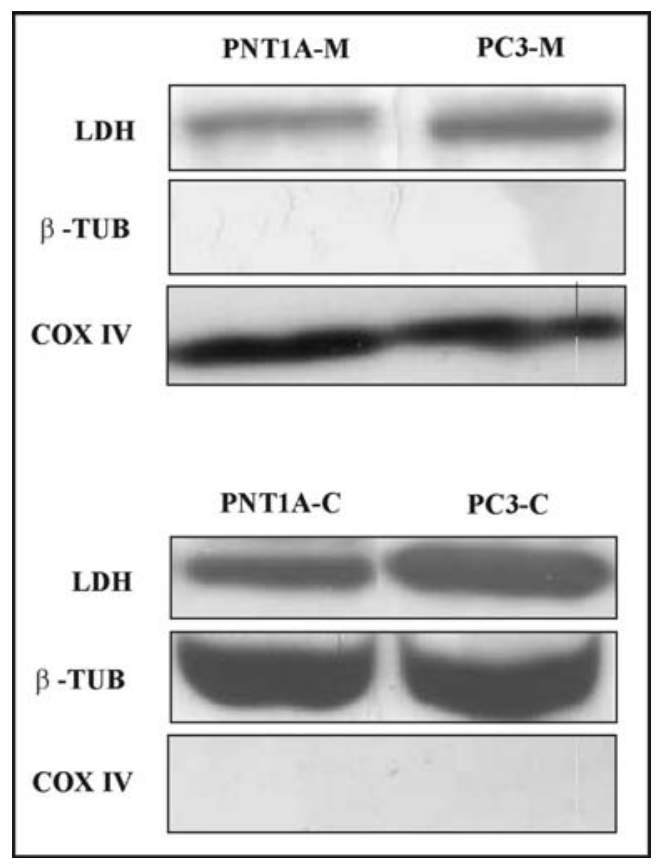

Figure 4. Western blot analysis of either PNT1A-M or PC3-M extracts. Solubilised mitochondria (PNT1A-M, PC3-M) and cytosolic fractions (PNT1A-C, PC3-C) (20 $\mu \mathrm{g}$ protein loaded in each lane) were analyzed by Western blot analysis using LDH-specific antibody, as described in Materials and methods. Mitochondrial purity was confirmed by detection of the presence of the mitochondrial marker protein COX IV and by the absence of the cytosolic marker protein $\beta$-TUB.

$\left(\mathrm{NH}_{4}-\mathrm{Ac}\right)$, a highly penetrant anion which enters mitochondria via diffusion (31). No significant swelling was found in $0.25 \mathrm{M}$ sucrose, showing the intactness of the mitochondrial membranes. Both PNT1A-M and PC3-M were also found to swell in ammonium pyruvate $\left(\mathrm{NH}_{4}-\mathrm{PYR}\right)$ and ammonium phosphate $\left(\mathrm{NH}_{4}-\mathrm{Pi}\right)$ solutions. In the presence the thiol reagent mersalyl (200 nmol/mg mitochondrial protein) which cannot enter mitochondria and can inhibit a variety of carriers (32), inhibition of swelling in $\mathrm{NH}_{4}$ - L-LAC, but not in $\mathrm{NH}_{4}$-Ac, was found, this showing that L-LAC transport occurs in a carrier-mediated manner and that thiol group/s is/are present in the carrier/s. Consistently, cysteine $(2 \mathrm{mM})$ addition resulted in the removal of swelling inhibition by mersalyl (not shown).

Mitochondria isolated from prostate cells contain their own L-lactate dehydrogenase. Having established that L-LAC can enter mitochondria, the existence of the mLDH was monitored via immunological analysis. In a first set of experiments Western blot analysis was carried out by using anti-LDH antibody. COX IV was used as a mitochondrial marker and challenge with an anti-COX IV antibody showed constant levels of protein (Fig. 4) (for details Materials and methods). Fig. 4 shows the occurrence of the novel mLDH in both PNT1A-M and PC3-M but at different protein levels. The ratio $\mathrm{mLDH} / \mathrm{COX} \mathrm{IV}$ used to normalize protein levels, was $\sim 2.00 \pm 0.01$ times higher in PC3-M compared with that found in PNT1A-M ( $<<0.05)$. As a control of mitochondrial purity, both mitochondrial samples were subjected to immuno- logical analysis by using an antibody raised against B-TUB, a protein restricted to cytoplasm. No cross-reacting material was found, this confirming that all mitochondrial preparations were completely free of cytosolic contamination.

In parallel the same analysis was carried out on the cytosolic fraction of either PNT1A (PNT1A-C) or PC3 cells (PC3-C). As expected both cLDH and B-TUB, but not COX IV, were recognized by their antibodies. The ratio cLDH/ßTUB used to normalize protein levels, was $\sim 1.9 \pm 0.01$ times higher in PC3-C compared with that found in PNT1A-C $(\mathrm{p}<0.05)$.

In another set of experiments the existence of the prostate mLDH was functionally investigated by checking (Fig. 1) (25), the ability of externally added L-LAC to cause uptake of oxygen, using either PNT1A or PC3 cell homogenates (2 mg cell protein each) (Fig. 5). First we confirmed that mitochondria were essentially intact as shown by the lack of activity of both ADK and GDH, marker enzymes of the intermembrane space and of the matrix, respectively (22), in homogenate supernatants (Materials and methods). Homogenates were incubated in the presence of $1 \mu \mathrm{M}$ FCCP, used to maximize the rate of the intramitochondrial oxidation of respiratory substrates. Following the addition of $5 \mathrm{mM} \mathrm{L-LAC}$ to either PNT1A or PC3 cell homogenates, oxygen uptake occurred at a rate of $\sim 0.6$ and 1.4 natom $\mathrm{O} \mathrm{x} \mathrm{min}{ }^{-1} \mathrm{x} \mathrm{mg}^{-1}$ cell protein, respectively, thus showing that prostate cell mitochondria oxidize L-LAC rather poorly but that the rate of L-LAC oxidation increases in cancer cells (Fig. 5A and B). In three separate experiments the rates were $0.60 \pm 0.05$ and $1.3 \pm 0.2$ natom $\mathrm{O} \times \mathrm{min}^{-1} \mathrm{x} \mathrm{mg}^{-1}$ protein in PNT1A and PC3 cell homogenates, different as judged by a statistical analysis carried out using the Student's t test $(\mathrm{p}<0.05)$, respectively. In both cases oxygen consumption was abolished by OXAM (10 $\mathrm{mM})$. Interestingly PYR (5 mM) failed to cause oxygen consumption when added to either cell homogenate under the same experimental conditions (data not shown). In the same experiment, we checked whether prostate mitochondria oxidized succinate (SUC, $5 \mathrm{mM}$ ), used as a respiratory substrate, either in the absence or presence of $1 \mathrm{mM}$ ADP. The respiratory control ratios (i.e. the ratio of the rate of oxygen uptake in the presence, state 3, or absence of ADP, state 4), were 3.5 in PNT1A and 2.5 in PC3 cell homogenates (insets to Fig. 5). Rates of SUC oxidation found in PC3 cell homogenates were higher than those found in PNT1A cell homogenates, both in state $4\left(0.2\right.$ and 0.6 natom $\mathrm{O} \times \min ^{-1} \mathrm{x}$ $\mathrm{mg}^{-1}$ protein, respectively) and state 3 ( 0.7 and 1.5 natom $\mathrm{O}$ $\mathrm{x} \mathrm{min}^{-1} \mathrm{x} \mathrm{mg^{-1 }}$ protein, respectively). In three separate experiments oxygen consumption by PNT1A and PC3 cell homogenates added with SUC ( $5 \mathrm{mM})$ occurred with rates of $0.25 \pm 0.1$ and $0.60 \pm 0.1$ natom $\mathrm{O} \times \mathrm{min}^{-1} \times \mathrm{mg}^{-1}$ protein in state 4 and $0.75 \pm 0.05$ and $1.50 \pm 0.1$ natom $\mathrm{O} \times \mathrm{min}^{-1} \mathrm{x} \mathrm{mg}^{-1}$ protein in state 3 , respectively. These results confirm that energy metabolism in prostate cells is poorly dependent on oxidative phosphorylation $(15,16)$. In the same experiment L-LAC, but not PYR, addition was found to cause increase of the intramitochondrial pyridine nucleotide fluorescence (Fig. 2) (data not shown).

Thus, both to confirm that PNT1A-M and PC3-M contain their own $\mathrm{mLDH}$, and to determine the LDH intramitochondrial localization, we investigated the presence of 
A

PNT1A

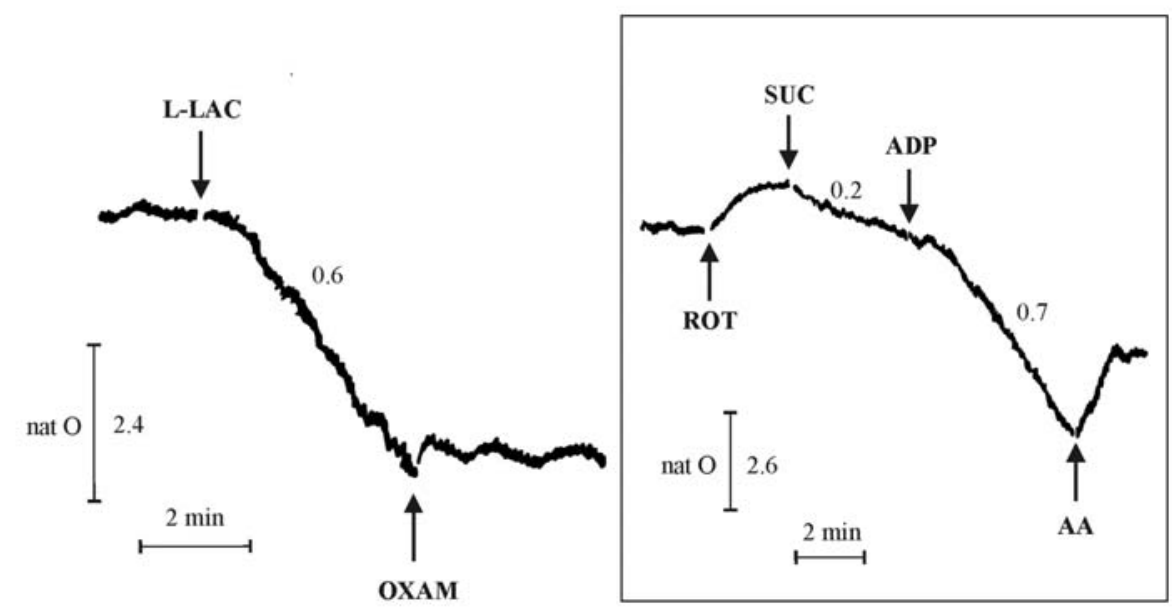

B

PC3

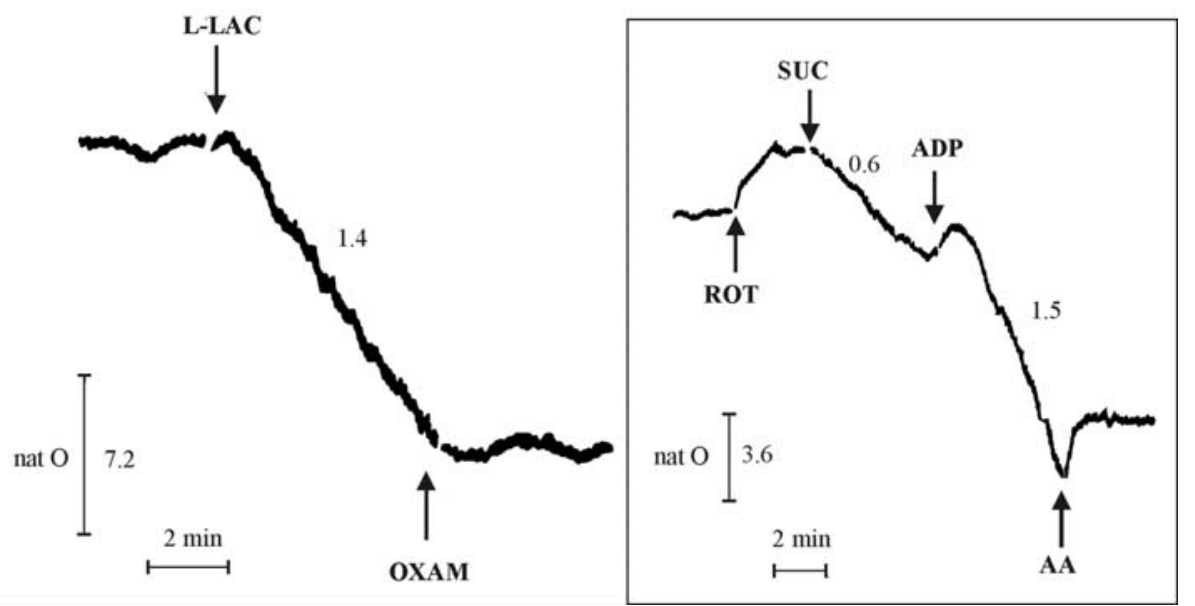

Figure 5. Oxygen uptake by homogenates from either PNT1A or PC3 cells added with L-lactate. Homogenates (2 mg protein) from either PNT1A (A) or PC3 cells (B) were incubated at $25^{\circ} \mathrm{C}$ in PBS medium (final volume $0.5 \mathrm{ml}$ ) in the presence of FCCP $(1 \mu \mathrm{M})$ and oxygen uptake was measured as a function of time. At the arrows the following additions were made: L-lactate (L-LAC, $5 \mathrm{mM})$, oxamate (OXAM, $10 \mathrm{mM})$. In the insets cell homogenates were incubated under the same experimental conditions in the absence of FCCP. At the arrows the following additions were made: rotenone (ROT, $2 \mu \mathrm{g}$ ), succinate (SUC, $5 \mathrm{mM})$, ADP $(1 \mathrm{mM})$, antimycin A (AA, $1.5 \mu \mathrm{g})$. Numbers along the curves are rates of oxygen uptake expressed as natom $\mathrm{O} \times \mathrm{min}^{-1} \mathrm{x} \mathrm{mg}^{-1} \mathrm{protein}$.

mLDH activity in isolated mitochondria. To do this, both PNT1A-M (Fig. 6A) and PC3-M (Fig. 6B) (0.02 mg each) were incubated with ROT $(2 \mu \mathrm{g})$ followed by either NADH $(0.2 \mathrm{mM})$ plus PYR $(1 \mathrm{mM})$ (traces a and b) or NAD ${ }^{+}(1 \mathrm{mM})$ plus L-LAC (5 mM) (traces a' and $\left.\mathrm{b}^{\prime}\right)$. These substrate pairs allow for monitoring the $\mathrm{LDH}$ reaction in the sense of $\mathrm{NADH}$ oxidation or $\mathrm{NAD}^{+}$reduction, respectively; in both cases the absorbance at $334 \mathrm{~nm}$ was measured as a function of time (Materials and methods). No significant change in the absorbance was found in either case (Fig. 6A and B), this showing both the absence of cytosolic LDH contamination and more importantly the absence of a mitochondrial $\mathrm{NAD}^{+}$-linked LDH located in external mitochondrial compartments which include the outer membrane, the intermembrane space and the outer side of the inner mitochondrial membrane. To reveal the existence of $\mathrm{mLDH}$ inside mitochondria, they were solubilised by adding the detergent Triton X-100 (TX-100, $0.1 \%$ ). mLDH activity was then found as revealed by the decrease/increase of absorbance for NADH plus PYR or
$\mathrm{NAD}^{+}$plus L-LAC used as substrate pair, respectively. In a parallel experiment control was also made that after TX-100 addition, mitochondrial solubilisation led to an immediate absorbance decrease after which no further significant absorbance change occurred (not shown). The reaction rates were 0.40 or $0.95 \mu$ mol NADH oxidised $\mathrm{x} \mathrm{min} \mathrm{m}^{-1} \mathrm{x} \mathrm{mg}^{-1}$ mitochondrial protein and 0.10 or $0.27 \mu$ mol $\mathrm{NAD}^{+}$reduced $\mathrm{x} \min ^{-1} \mathrm{x} \mathrm{mg}^{-1}$ mitochondrial protein for either PNT1A-M or PC3-M, respectively. In all cases the changes of absorbance were abolished when OXAM $(10 \mathrm{mM})$ was included in the reaction system. These results clearly demonstrate the presence of mLDH located in the inner mitochondrial compartments which include the inner side of the inner mitochondrial membrane and the matrix, and that at the substrate concentrations used $\mathrm{mLDH}$ is most active in cancer cells.

Moreover, the possibility was considered that mitochondria were contaminated by plasma membrane vesicle releasing cLDH on TX-100 treatment. That this is not the case is shown in Fig. 6: in both TX-100-treated PNT1A-M and PC3-M, 
$\mathbf{A}$
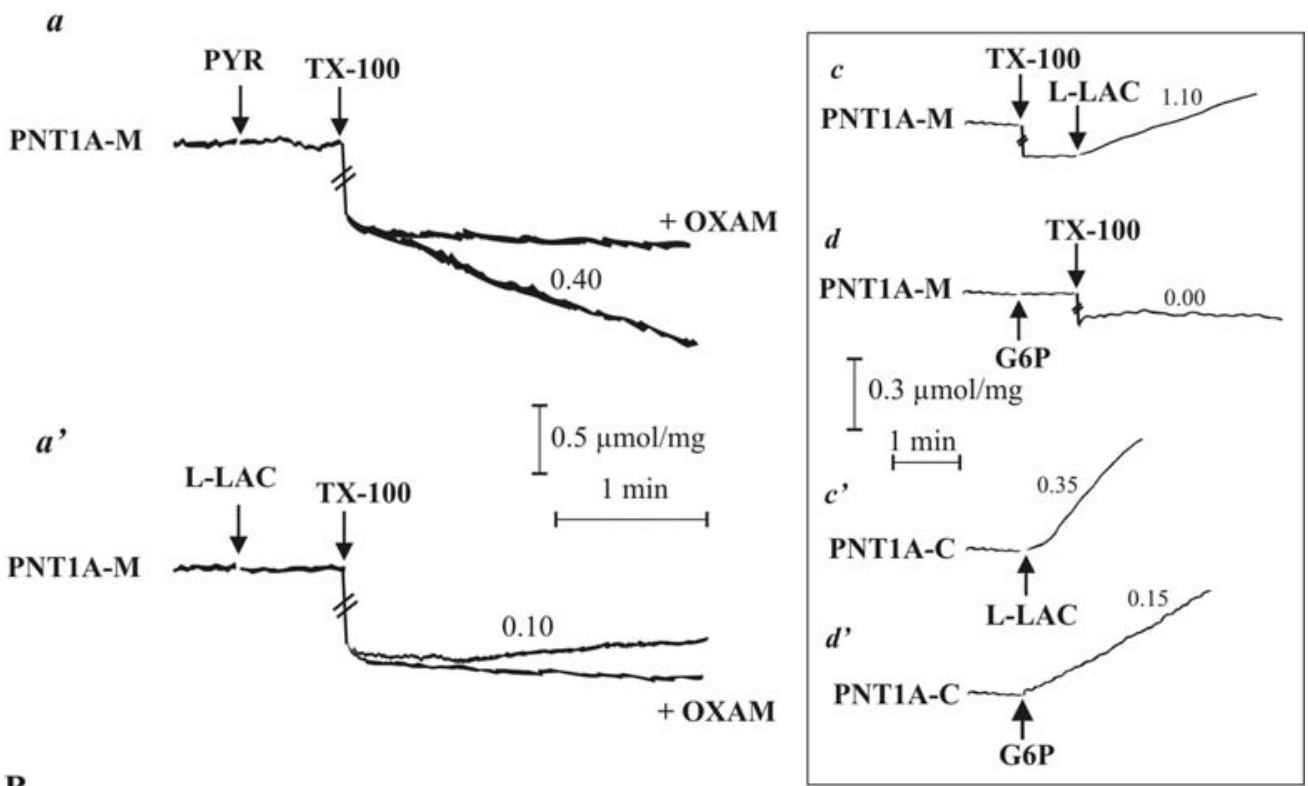

B
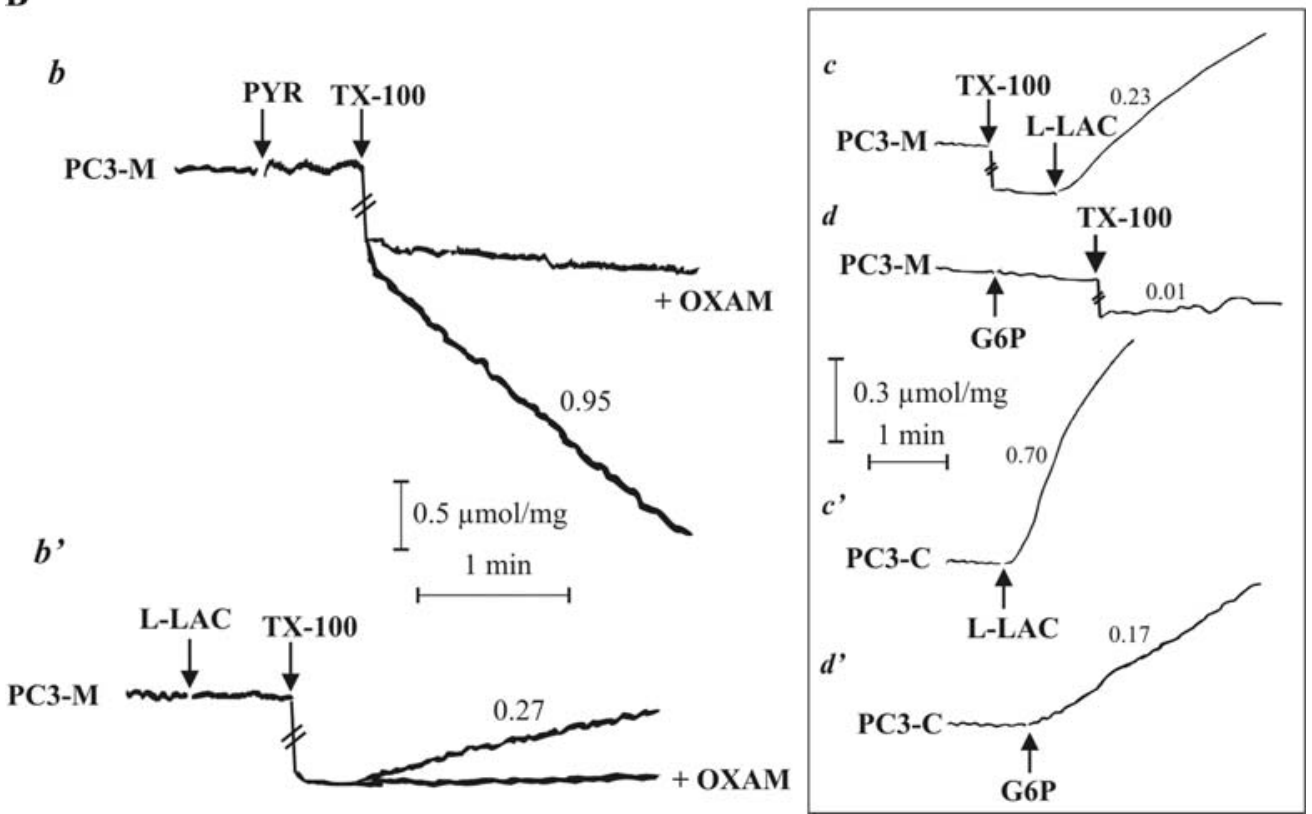

Figure 6. LDH assay in mitochondria from either PNT1A or PC3 cells. Mitochondria (0.02 mg protein) from either PNT1A (A) or PC3 (B) cells were incubated at $25^{\circ} \mathrm{C}$ in $2 \mathrm{ml}$ standard medium consisting of $0.25 \mathrm{M}$ sucrose, $10 \mathrm{mM} \mathrm{KCl}, 1.5 \mathrm{mM} \mathrm{MgCl}{ }_{2}, 1 \mathrm{mM} \mathrm{Na}-\mathrm{EDTA}, 20 \mathrm{mM}$ HEPES-KOH (pH 7.4) plus rotenone (ROT, $2 \mu \mathrm{g})$ and then added with either NADH $(0.2 \mathrm{mM})(\mathrm{a}, \mathrm{b})$ and $\mathrm{NAD}^{+}(1 \mathrm{mM})\left(\mathrm{a}^{\prime}, \mathrm{b}^{\prime}\right)$. In the insets both LDH (c, c') and glucose-6-phosphate dehydrogenase $\left(\mathrm{d}, \mathrm{d}^{\prime}\right)$ activity were assayed in either mitochondrial (PNT1A-M, PC3-M) or cytosolic (PNT1A-C, PC3-C) fractions incubated in 2 ml standard medium ( $\mathrm{pH}$ 7.4) plus rotenone (ROT, $2 \mu \mathrm{g})$ and then added with either $\mathrm{NAD}^{+}(1 \mathrm{mM})$ or $\mathrm{NADP}^{+}(0.25 \mathrm{mM})$, respectively. At the arrows the following additions were made: pyruvate (PYR, $1 \mathrm{mM}$ ), L-lactate (L-LAC, $5 \mathrm{mM}$ ), Triton X-100 (TX-100, 0.1\%), glucose-6-phosphate (G6P, $10 \mathrm{mM})$. Where indicated oxamate (OXAM, $10 \mathrm{mM}$ ) was previously incubated with mitochondria. The rate of absorbance change at $334 \mathrm{~nm}$, measured as the tangent to the initial part of the progress curve, is expressed as $\mu$ mol NADH oxidized/NAD(P)+ reduced $\mathrm{x} \mathrm{min}^{-1} \mathrm{x} \mathrm{mg}^{-1}$ mitochondrial or cytosolic protein.

where $\mathrm{mLDH}$ was found (traces $\mathrm{c}$ in the insets to Fig. 6), no activity of the glucose-6-phosphate dehydrogenase a cytosolic marker enzyme, occurs (traces $d$ in the insets to Fig. 6).

On the other hand, both cLDH and glucose-6-phosphate dehydrogenase activities were found in PNT1A-C and in PC3-C cells ( $\mathrm{c}^{\prime}$ and $\mathrm{d}^{\prime}$ in the insets to Fig. 6). Interestingly cLDH reaction rate was 0.35 and $0.70 \mu \mathrm{mol} \mathrm{NAD}^{+}$reduced $\mathrm{x}$ $\mathrm{min}^{-1} \mathrm{x} \mathrm{mg}^{-1}$ protein for either PNT1A-CFor PC3-C, respectively, this showing that cLDH activity increases in cancer cells.
In order to ascertain whether mLDHs in PNT1A-M and in PC3-M differ from one another, solubilised PNT1A-M and PC3-M (0.02 mg protein each) were used and the dependence of LDH reaction rate was studied as a function of increasing concentrations of either PYR (in the presence of $0.2 \mathrm{mM}$ NADH) or L-LAC (in the presence of $1 \mathrm{mM} \mathrm{NAD}^{+}$) at $\mathrm{pH}$ values ranging from 6.5 to 8.0 (Fig. 7A). Saturation kinetics were found in all cases. The $\mathrm{K}_{\mathrm{m}}$ i.e. the substrate concentration at which half $\mathrm{V}_{\max }$ is measured, and $\mathrm{V}_{\max }$ values of the reaction from three separate experiments are reported 


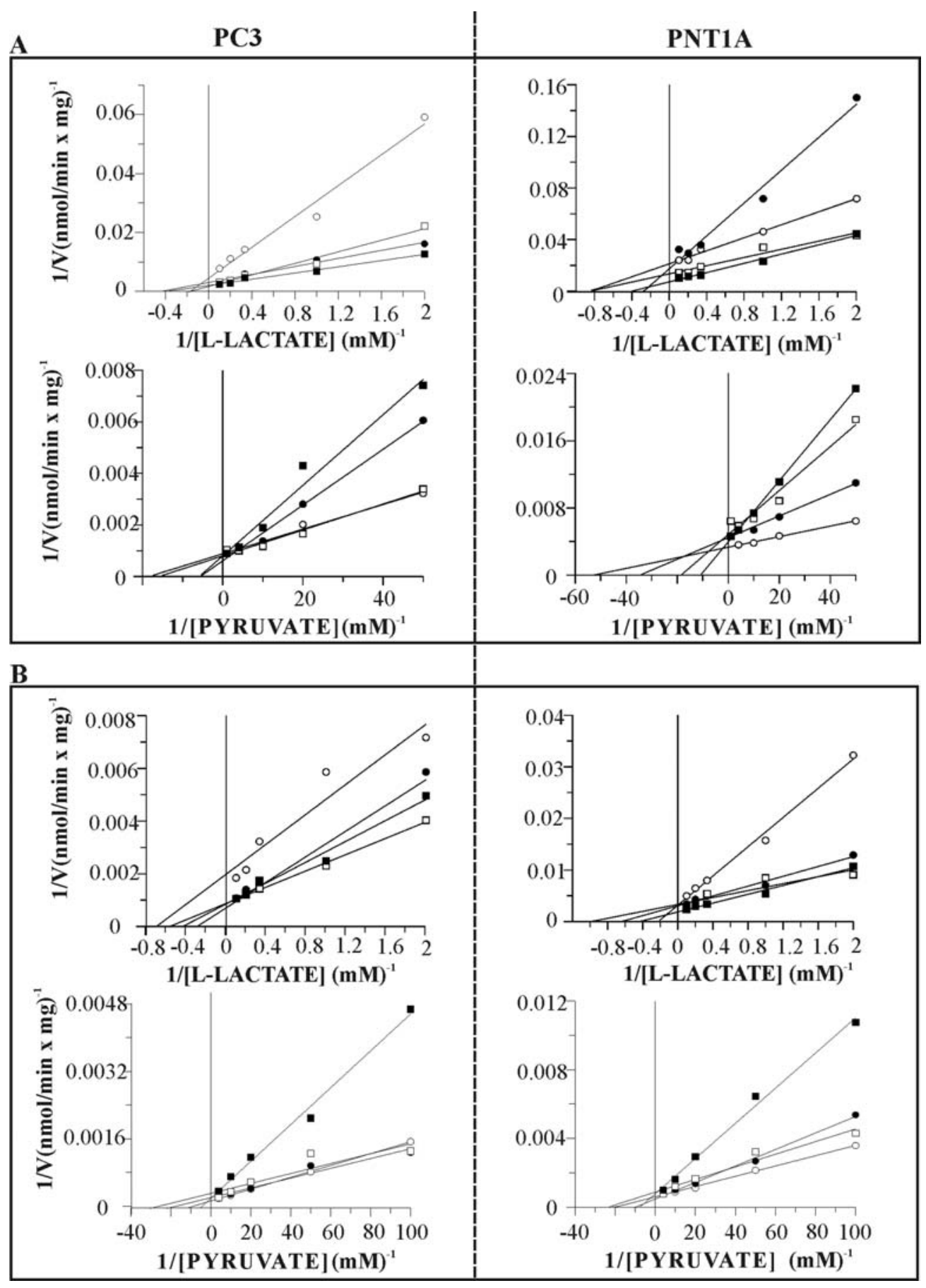

Figure 7. The dependence of $\mathrm{mLDH}$ activity on increasing concentrations of either L-lactate or pyruvate, measured at different pH values. Experimental conditions were as in Fig. 6. Solubilised mitochondria (A) or cytosolic fractions (B) (0.02 mg protein each) from either PNT1A or PC3 cells were incubated in $2 \mathrm{ml}$ of standard medium, the pH of which was adjusted to $6.5(\circ), 7.0(\bullet), 7.4(\square)$ or $8.0(\bullet)$ with either HEPES or KOH. Pyruvate or L-lactate was added at the indicated concentrations in the presence of either NADH $(0.2 \mathrm{mM})$ or NAD $(1 \mathrm{mM})$, respectively. The rates of absorbance change at 334 nm, measured

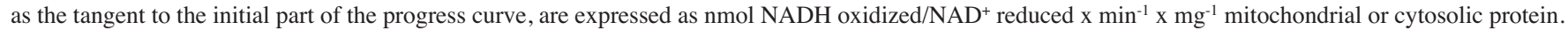

with their standard deviations in Table I. As expected in the light of the results in Fig. 4, the comparison of $\mathrm{V}_{\max }$ values confirms that PC3 mLDH exhibits activity significantly higher $(\mathrm{p}<0.05)$ than that of the enzyme from PNT1A-M at all the $\mathrm{pH}$ values investigated. Significant differences in $\mathrm{mL}-\mathrm{LDH}$ $\mathrm{K}_{\mathrm{m}}$ values $(\mathrm{p}<0.05)$ were found only for PYR at $\mathrm{pH} 7.0$ and for L-LAC at $\mathrm{pH} 7.4$.
A similar experiment was carried out to compare the mLDHs with the cytosolic enzymes (Fig. 7B). The $\mathrm{K}_{\mathrm{m}}$ and $\mathrm{V}_{\max }$ values of the reaction from three separate experiments are reported with their standard deviations in Table I. In a fairly good agreement with Figs. 4 and $6, \mathrm{~V}_{\max }$ values for the LDH in PC3-C were higher than those of PNT1A-C. On the other hand, cLDH $\mathrm{K}_{\mathrm{m}}$ values for PYR differ significantly in 
Table I. The kinetic parameters of the $\mathrm{LDH}$ reactions as calculated in $\mathrm{pH}$ range 6.5-8.0. ${ }^{\mathrm{a}}$

\begin{tabular}{|c|c|c|c|c|c|}
\hline \multicolumn{6}{|c|}{$\begin{array}{l}\text { L-lactate dehydrogenase reactions } \\
\text { Pyruvate } \rightarrow \text { L-lactate }\end{array}$} \\
\hline & $\mathrm{pH}$ & 6.5 & 7.0 & 7.4 & 8.0 \\
\hline PNT1A-M & $\mathrm{V}_{\max }$ & $237 \pm 92$ & $357 \pm 127$ & $432 \pm 43$ & $359 \pm 28$ \\
\hline PC3-M & $\mathrm{V}_{\max }$ & $851 \pm 108$ & $1177 \pm 122$ & $1021 \pm 51$ & $1245 \pm 157$ \\
\hline PNT1A-M & $\mathrm{K}_{\mathrm{m}}$ & $0.015 \pm 0.005$ & $\times 0.03 \pm 0.008$ & $0.04 \pm 0.003 \S$ & $0.15 \pm 0.07$ \\
\hline PC3-M & $\mathrm{K}_{\mathrm{m}}$ & $0.02 \pm 0.009+$ & $\times 0.05 \pm 0.005$ & $0.05 \pm 0.002 \boldsymbol{\nabla}$ & $0.19 \pm 0.08$ \\
\hline PNT1A-C & $\mathrm{V}_{\max }$ & $1594 \pm 173$ & $1759 \pm 348$ & $2120 \pm 653$ & $2170 \pm 477$ \\
\hline PC3-C & $\mathrm{V}_{\max }$ & $5525 \pm 755$ & $5642 \pm 516$ & $6170 \pm 425$ & $5658 \pm 458$ \\
\hline PNT1A-C & $\mathrm{K}_{\mathrm{m}}$ & $\bullet 0.03 \pm 0.01$ & $0.05 \pm 0.01 \bullet$ & $* 0.09 \pm 0.02 \S$ & $0.21 \pm 0.01$ \\
\hline PC3-C & $\mathrm{K}_{\mathrm{m}}$ & $\bullet 0.06 \pm 0.01+$ & $0.07 \pm 0.01$ & $* 0.13 \pm 0.005 \nabla$ & $0.20 \pm 0.06$ \\
\hline \multicolumn{6}{|c|}{ L-lactate $\rightarrow$ Pyruvate } \\
\hline & $\mathrm{pH}$ & 6.5 & 7.0 & 7.4 & 8.0 \\
\hline PNT1A-M & $\mathrm{V}_{\max }$ & $77 \pm 23$ & $79 \pm 10.5$ & $150 \pm 45$ & $115 \pm 35$ \\
\hline PC3-M & $\mathrm{V}_{\max }$ & $267 \pm 79$ & $476 \pm 38$ & $417 \pm 89$ & $552 \pm 130$ \\
\hline PNT1A-M & $\mathrm{K}_{\mathrm{m}}$ & $3.3 \pm 1.9$ & $1.8 \pm 0.4$ & $1.5 \pm 0.2$ А & $3 \pm 1.6$ \\
\hline PC3-M & $\mathrm{K}_{\mathrm{m}}$ & $4.0 \pm 0.7$ & $2.8 \pm 1.1$ & $2.7 \pm 0.6 \wedge$ & $2.6 \pm 1.2$ \\
\hline PNT1A-C & $\mathrm{V}_{\max }$ & $240 \pm 31$ & $371 \pm 43$ & $425 \pm 40$ & $468 \pm 21$ \\
\hline PC3-C & $\mathrm{V}_{\max }$ & $643 \pm 96$ & $980 \pm 156$ & $1325 \pm 226$ & $1827 \pm 283$ \\
\hline PNT1A-C & $\mathrm{K}_{\mathrm{m}}$ & $2.6 \pm 0.9$ & $2.1 \pm 0.8$ & $2.0 \pm 1.0$ & $1.5 \pm 0.4$ \\
\hline PC3-C & $\mathrm{K}_{\mathrm{m}}$ & $2.3 \pm 0.6$ & $2.1 \pm 0.1$ & $2.3 \pm 0.6$ & $3.3 \pm 2$ \\
\hline
\end{tabular}

${ }^{a}$ The mean values of the kinetic parameters of the L-lactate dehydrogenase were obtained from three separate experiments carried out as in Fig. 7 on either solubilised PNT1A-M and PC3-M or the respective cytosolic fractions (PNT1A-C and PC3-C). $\mathrm{V}_{\max }$ and $\mathrm{K}_{\mathrm{m}}$ values (with their standard deviations) are expressed as nmol of $\mathrm{NAD}^{+}$-reduced/NADH-oxidized $\mathrm{x} \mathrm{min}{ }^{-1} \mathrm{x} \mathrm{mg}^{-1}$ mitochondrial or cytosolic protein and mM, respectively. Each symbol pair indicate $\mathrm{K}_{\mathrm{m}}$ values which differ significantly from one another according to the Student's $t$ test ( $\mathrm{p}<0.05$ ).

normal with respect to cancer cells at $\mathrm{pH} 6.5$ and 7.4 . Moreover, significant differences between $\mathrm{mLDH}$ and $\mathrm{cLDH}$ $\mathrm{K}_{\mathrm{m}}$ values for PYR were found at $\mathrm{pH}$ values ranging from 6.5 to 7.4 in both PNT1A and PC3 cells.

The results in Table I show that both mLDHs and cLDHs of PC3 cells differ from those of PNT1A cells. Such a conclusion was confirmed by plotting the $\mathrm{V}_{\max }$ mean values reported in Table I as a function of the $\mathrm{pH}$ (Fig. 8): the $\mathrm{pH}$ profiles provide further evidence that $\mathrm{c}$ and $\mathrm{mLDHs}$ differ from one another in both PNT1A and PC3 cells with PYR plus NADH (compare traces, Fig. 8Aa, Ba) or L-LAC plus $\mathrm{NAD}^{+}($Fig. $8 \mathrm{Ab}, \mathrm{Bb})$ used as substrate pairs and that the cLDHs differ from mLDHs. In particular the slopes of the lines fitting the experimental data were different as judged by a statistical analysis carried out with the Student's t-test, with the exception of Fig. 8Ba.

\section{Discussion}

Even though a detailed research into the intermediary metabolism of normal and neoplastic prostate is essential to future significant advances in understanding and dealing with prostate cancer in a metabolic therapy, to date in terms of (19) 'the metabolism of the prostate has been a seriously neglected and largely ignored area of prostate research'. In particular, given that L-LAC was commonly considered as a waste product of metabolism in cancer cells (14), including prostate cancer cells (15), to be exported to the bloodstream, L-LAC metabolism in prostate cells was completely neglected. Herein we show (Fig. 9) i) that externally added L-LAC can enter both normal and cancer prostate cells; ii) that L-LAC is metabolized essentially by mitochondria, iii) that as in other mammalian cells $(10,25,26,33)$, an $\mathrm{mLDH}$ exists different from the cytosolic enzyme and highly expressed and more active in PC3 cells, and iv) that in cancer cells the cLDH level and activity are higher with respect to those of normal cells and that these cLDHs are functionally different.

As neurons and muscle cells (10), both normal and cancer prostate cells can take up and metabolise externally added L-LAC (Figs. 1 and 2). This has definitely been shown in experiments in which we found $\mathrm{NAD}(\mathrm{P}) \mathrm{H}$ fluorescence increases as a result of the addition of L-LAC to either 
A
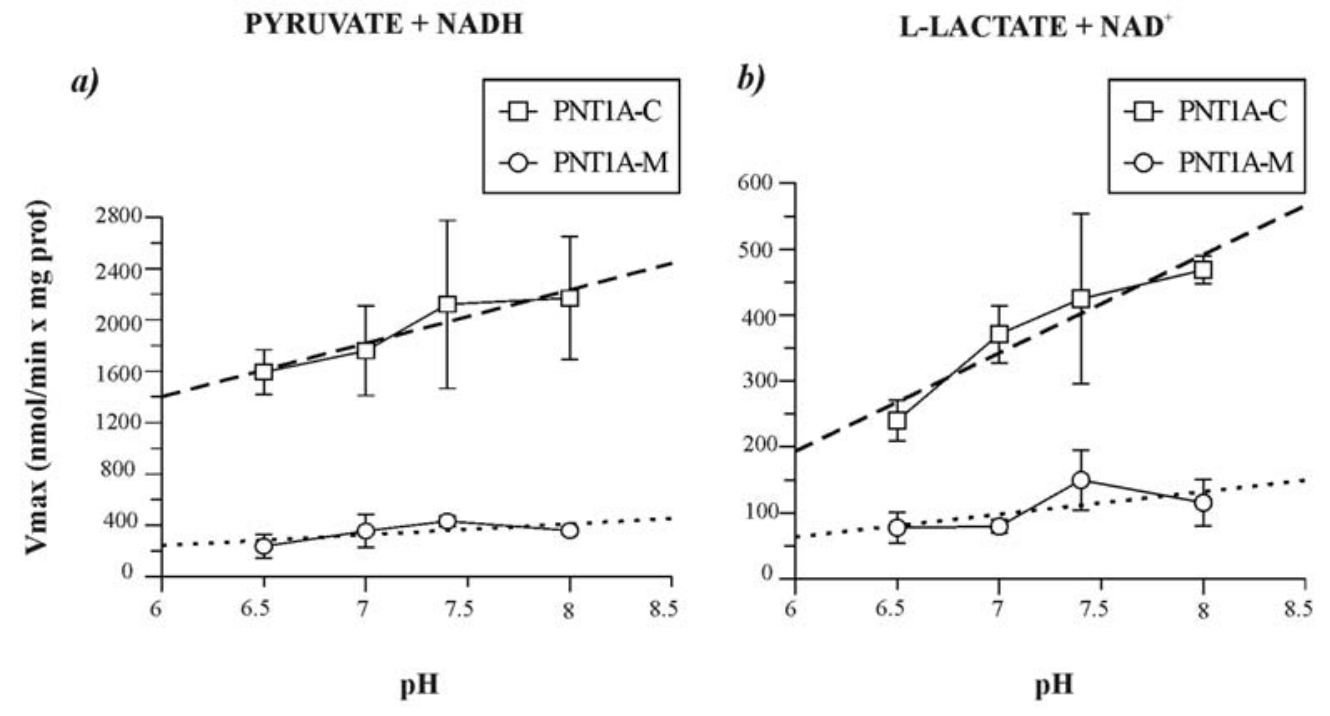

B

\section{PYRUVATE + NADH}

a)

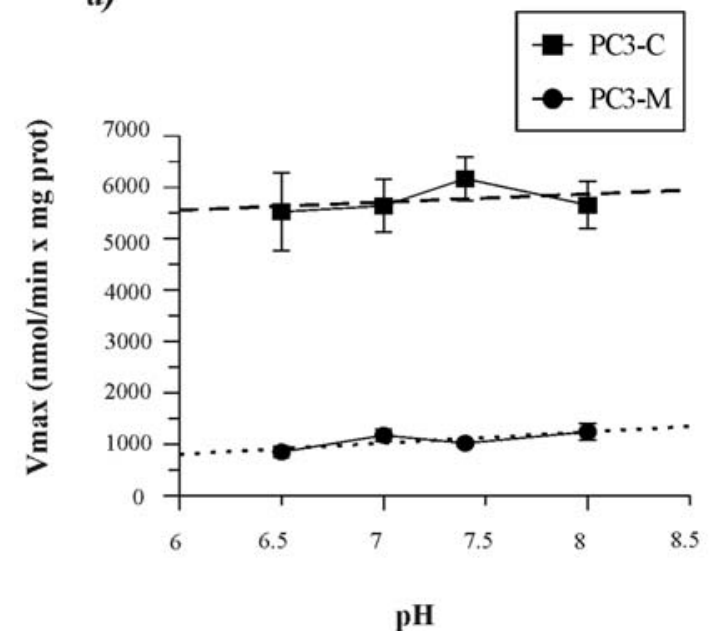

\section{L-LACTATE + NAD}

\section{b)}

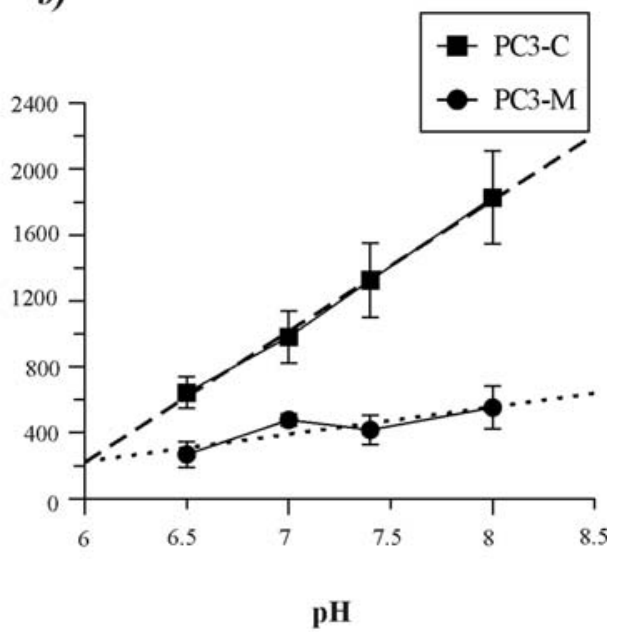

Figure 8. The $\mathrm{pH}$ profile of $\mathrm{mLDH}$ and cLDH of either PNT1A or PC3 cells. The $\mathrm{pH}$ profiles were obtained by plotting the $\mathrm{V}_{\max }$ mean values reported in Table I as a function of $\mathrm{pH}$. Pyruvate plus NADH or L-LAC plus NAD ${ }^{+}$were used as substrate pairs. Dotted lines have been obtained from linear best fitting of the experimental data.

PNT1A or PC3 cells. At first glance, one could explain such a result as depending on PYR formation in the cytoplasm and subsequent PYR uptake and metabolism inside mitochondria via PDH. However, the failure of externally added PYR to cause both oxygen uptake and $\mathrm{NAD}(\mathrm{P}) \mathrm{H}$ formation in not consistent with such a conclusion; in addition ARS a powerful inhibitor of PDH (30), does not completely prevent NAD(P)H formation. Thus we are forced to conclude that L-LAC once inside the prostate cells is essentially metabolised inside mitochondria. Accordingly, due both to the high affinity of the cLDHs for pyruvate $\left(\mathrm{K}_{\mathrm{m}}\right.$ values $\left.\sim 0.06 \mathrm{mM}\right)$ and to the thermodynamics of this reaction, which is completely shifted to the right, we assume that L-LAC is the ultimate product of glycolysis. Such a conclusion is consistent with the special prostate metabolism which results, mainly in normal cells, in a huge formation of citrate to be exported outside mitochondria and in the extracellular fluid, with a truncated citric cell cycle and a poor oxidative phosphorylation, this requiring glycolysis as the main ATP producing pathway.

Although in this study we have not investigated L-LAC transport in prostate mitochondria in great detail, in light of the swelling experiments, in which we found spontaneous swelling of mitochondria suspended in $\mathrm{NH}_{4}$-L-LAC (Fig. 3), we confirm that prostate mitochondria can take up L-LAC with net carbon uptake in a proton-compensated manner (31). That L-LAC uptake can occur in a carrier-mediated manner, and not via diffusion, is suggested by the evidence that PNT1A-M and PC3-M show different swelling rate and amplitude in $\mathrm{NH}_{4}$-L-LAC and other ammonium salt solutions, including ammonium acetate which can enter mitochondria 
PROSTATE CELL

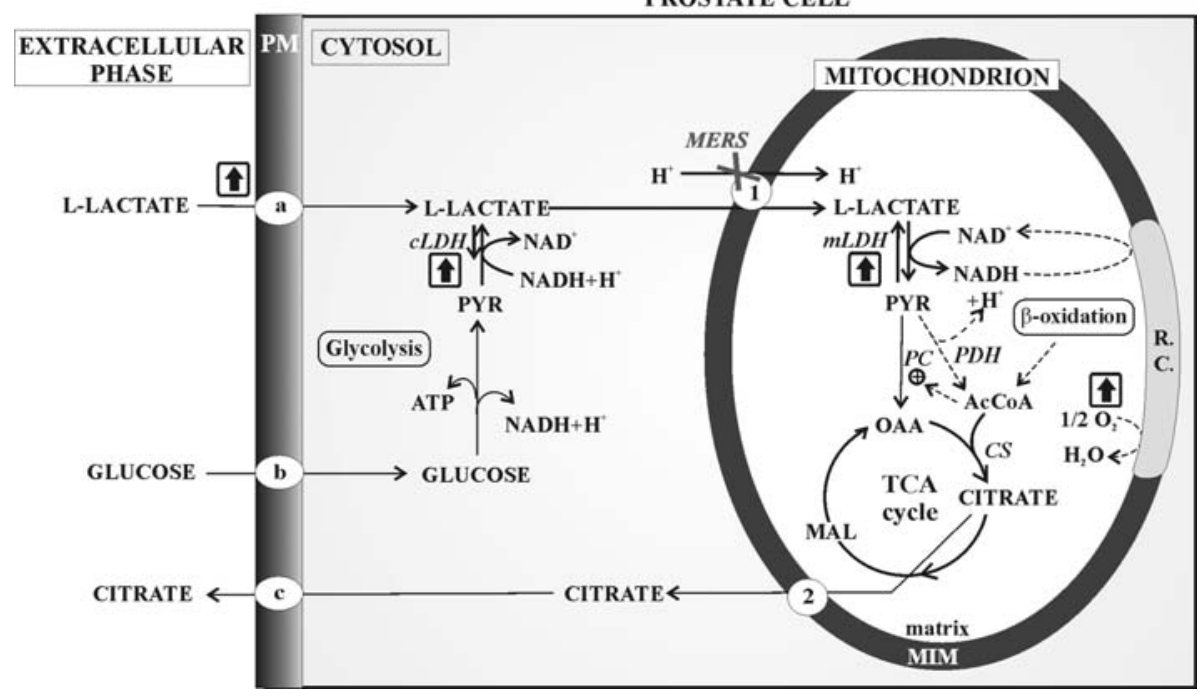

Figure 9. The L-lactate metabolism in prostate cells. L-LAC can both enter prostate cells perhaps via a monocarboxylate translocator and be formed in the cytosol from glucose, taken up via its own translocator, via glycolysis. Inside the cell L-LAC can be i) hardly catabolized by cLDH, ii) transported into mitochondria in a carrier-mediated manner via the putative $\mathrm{L}-\mathrm{LAC} / \mathrm{H}^{+}$symporter inhibited by mersalyl. Inside mitochondria $\mathrm{L}-\mathrm{LAC}$ is oxidised by the mLDH, producing pyruvate. In light of the poor oxygen consumption (Fig. 5) and since fatty acid oxidation is the bioenergetic dominant pathway (18) in prostate, LLAC metabolism is suggested to lead to citric cycle anaplerosis to give OAA via pyruvate carboxylase, activated by acetyl-CoA. Citrate could be then formed to be used essentially in fatty acid synthesis in PC3 cells and exported in the extracellular fluid in PNT1A cells. In both cases citrate transport outside mitochondria is assumed to occur via the tricarboxylate translocator. Glucose metabolism is assumed to produce NADPH needed for fatty acid synthesis to occur. - 1 refers to increase in the indicated processes occuring in PC3 cells. Main abbreviations: AcCoA, acetyl-CoA; MAL, malate; MIM, mitochondrial interal membrane; OAA, oxaloacetate; PM, plasma membrane; PYR, pyruvate; R.C., respiratory chain; RIB 5P, ribose 5-phosphate; TCA cycle, tricarboxylic acids cycle. Enzymes: $c L D H$, cytosolic LDH; $C L$, citrate lyase; $C S$, citrate synthase; $m L D H$, mitochondrial LDH; $P D H$, pyruvate dehydrogenase; $P C$, pyruvate carboxylase; MERS, mersalyl; mitochondrial carriers: 1, putative L-lactate $/ \mathrm{H}^{+}$symporter; 2 , tricarboxylate carrier. Plasma membrane carriers: a, monocarboxylate carrier; b, glucose translocator; c, citrate translocator.

via diffusion; more importantly, the inhibition of swelling by the non-penetrant thiol reagent mersalyl shows definitively the occurrence of carrier-mediated transport for L-LAC. The identity of the mitochondrial carrier/s that can transport L-LAC into mitochondria remains to be established. Unfortunately, at present, in spite of the enormous advances of proteomics (12) and genome data, a number of members of the mitochondrial carrier family remain uncharacterized. This applies to L-LAC transporter/s in prostate mitochondria. Thus, further functional studies are needed similar to those already reported $(25,26,32,33)$.

We found that in isolated mitochondria from prostate L-LAC oxidation took place at a rate low with respect to that found in mitochondria from other cells (10). Since SUC itself is oxidized at a rate $\sim 20-30$ times lower than those found either in rat liver mitochondria (26 and refs. therein) or in cerebellar granule cell homogenates ( 25 and refs. therein), in agreement with $(34,35)$ we conclude that in prostate mitochondria energy production from both glycolitic substrates, such as L-LAC, and SUC is very poor. These findings are consistent with a previous report (18) where fatty acid oxidation was reported as a dominant bioenergetic pathway in prostate cancer. In light of initial experiments reported in Fig. 5, we propose that mitochondrial coupling is less efficient in PC3-M (14). Depressed expression levels of the mitochondrial complexes of the oxidative phosphorylation were found in breast cancer cell mitochondria (36) and more recently reduced activity of the complex III and IV of the respiratory chain was reported in PC3 cells (37).
In light of (18) and since oxygen consumption in prostate is either very low $(34,37)$ or negligible when L-LAC and PYR, respectively, were used as substrate, L-LAC oxidation plays a minor/negligible role in energy production in prostate cells. Nonetheless, comparison made between PNT1A and PC3 cells suggests that L-LAC is oxidised with higher efficiency in cancer cells by a factor of $\sim 1.5$. In both cases we do not know the rate limiting step of oxygen consumption which involves transport across the plasma membrane and the multistep processes occurring inside the cell (Fig. 9); however since the relative increase of the rate of L-LAC oxidation when investigated in cell homogenates was higher (the ratio was $\sim 2.3$ ), we might assume that the rate of oxidation of L-LAC derived from extracellular compartments depends on the rate of L-LAC uptake into the cells perhaps mediated by a carrier belonging to the monocarboxylate carrier family (38). This issue requires further investigation.

Prostate $\mathrm{mLDH}$ is localised in the inner mitochondrial compartments as shown essentially by enzymatic assay (Fig. 6). The $\mathrm{mLDH}$ is an $\mathrm{NAD}(\mathrm{P})^{+}$-dependent enzyme, as shown by reduction of the intramitochondrial pyridine nucleotides (Figs. 2 and 6). In this regard, the mLDH of prostate cells is similar to the enzymes found in mitochondria from other sources (10). Normal and cancer mLDH differ functionally from one another as shown by the different $\mathrm{pH}$ profiles (Fig. 8) and by the difference in the kinetic parameters (Table I). The PC3 cell $\mathrm{mLDH}$ is essentially more active; consistently the mLDH level in PC3 cells is higher than that in PNT1A cells as shown by immunological 
analysis (Fig. 4). Based on different $\mathrm{K}_{\mathrm{m}}$ values and different $\mathrm{pH}$ profiles, cLDHs of PNT1A and PC3 cells which are apparently different from one another, differ also from the mitochondrial isoenzymes.

The existence of the $\operatorname{mLDH}(10,12)$ raises the question as to whether an active mitochondrial LDH would destroy the cytosolic/mitochondrial differences in the NADH/NAD ${ }^{+}$ratio that are fundamental to metabolism. This issue has already been discussed (32); thus by assuming that in prostate mitochondria, as in brain mitochondria the $\mathrm{NAD}^{+}$concentration is 8-20-fold higher than that of NADH and that PYR is actively oxidized via $\mathrm{PDH}$, we suggest that $\mathrm{mLDH}$ in vivo catalyses essentially L-LAC oxidation. Ultimately, the removal of the oxidation product by mitochondrial metabolism and perhaps by carrier-mediated transport (10) could overcome any thermodynamic difficulty. For instance the regulation of the carrier-mediated L-LAC traffic across the mitochondrial membrane could itself prevent the breakage of the redox compartmentation expected in the case of unregulated uptake/metabolism of L-LAC.

Prostate cells produce net citrate accumulation. Indeed, although glucose is the ultimate precursor for acetyl-CoA, only one quarter of it is metabolized in the mitochondria via the PDH reaction to acetyl-CoA mainly in cancer (39), probably due to the fact that prostate cancer exhibits slow glycolysis associated with increase of fatty acid metabolism relative to normal prostate (18). Since prostate cells cannot oxidize pyruvate (see above and ref. 40 in which externally added pyruvate proved to be ineffective in increasing the citrate level, in rat ventral prostate) we exclude that acetylCoA production is a result of the mitochondrial metabolism of L-LAC, being most of acetyl-CoA provided by fatty acid oxidation $(18,40)$. This raises the question as to the role of L-LAC metabolism in prostate. The new L-LAC scenario in both normal and cancer prostate cells is described in Fig. 9. We propose that inside mitochondria, metabolism of L-LAC produced via glycolysis and/or taken up from bloodstream, could lead to anaplerosis of citric acid cycle intermediates leading to oxaloacetate (OAA) production via mLDH and pyruvate carboxylase. As discussed in (15), OAA is supposed to derive from aspartate, but aspartate pools are modest compared to the cumulative huge amount of citrate secreted out of the tissue in normal cells and oxidized in the mitochondrial matrix/exported in the cytoplasm for fatty acid synthesis to occur in cancer cells. Moreover OAA could be also provided by the combined pool of proline, glutamine and glutamate, which via 2-oxoglutarate can supply carbon for the Krebs cycle. In initial experiments not reported here we found that both citrate and OAA can accumulate inside the mitochondria as a result of L-LAC addition.

Other fate of PYR might be to participate in the L-LAC/ PYR shuttle already shown to occur (10) thus contributing to transport of reducing equivalents from cytosol to mitochondria and reducing the cell acidosis. The occurrence of L-LAC metabolism in tumours is not unique; for instance as early as 1985 it was reported that some tumours release while others utilize blood L-LAC, and a few other tumours did neither $(41,42)$. Our work is novel, however, in showing that mitochondria can play a major role in L-LAC metabolism in cancer cells and that the LDH levels and activities increase in cancer cells. This might be used to develop an L-LAC-based metabolic therapy (43).

\section{Acknowledgements}

The authors wish to thank Dr Anna Atlante, Dr Arnaldo Arbini and Dr Loredana Moro for the helpful discussions in the preparation of the manuscript and Professor Shawn Doonan for his critical reading.

\section{References}

1. DeBerardinis RJ, Lum JJ, Hatzivassiliou G and Thompson CB: The biology of cancer: metabolic reprogramming fuels cell growth and proliferation. Cell Metab 7: 11-20, 2008.

2. Kroemer $\mathrm{G}$ and Pouyssegur J: Tumor cell metabolism: cancer's Achilles' heel. Cancer Cell 13: 472-482, 2008.

3. Mayevsky A: Mitochondrial function and energy metabolism in cancer cells: past overview and future perspectives. Mitochondrion 9: 165-179, 2009.

4. Vaupel P: Physiological properties of malignant tumours. NMR Biomed 5: 220-225, 1992.

5. Bouzier-Sore AK, Goodwin R, de Gannes FM, Valeins H, Voisin P, Canioni P and Merle M: Compartmentation of lactate and glucose metabolism in C6 Glioma Cells. J Bio Chem 273: 27162-27169, 1998.

6. Bouzier-Sore AK, Voisin P, Bouchaud V, Bezancon E, Franconi JM and Pellerin L: Competition between glucose and lactate as oxidative energy substrates in both neurons and astrocytes: a comparative NMR study. Eur J Neurosci 24: 1687-1694, 2006.

7. Walenta S, Schroeder T and Mueller-Klieser W: Lactate in solid malignant tumors: potential basis of a metabolic classification in clinical oncology. Curr Med Chem 11: 2195-2204, 2004.

8. Brentani MM and Nagai MA: Lactate dehydrogenase in breast carcinoma: correlation with estrogen and progesterone receptors. Cancer Detect Prev 6: 241-247, 1983.

9. Imaga, SS, Osmac M, Babic D, Sprem M, Vukelic B and Abramic M: Quantitative biochemical analysis of L-lactate dehydrogenase in human ovarian tissues: correlation with tumor grade. Int J Gynecol Cancer 15: 438-444, 2005.

10. Passarella S, de Bari L, Valenti D, Pizzuto R, Paventi G and Atlante A: Mitochondria and L-lactate metabolism. FEBS Lett 582: 3569-3576, 2008

11. Brooks GA: Cell-cell and intracellular lactate shuttles. J Physiol 587: 5591-5600, 2009.

12. Pagliarini DJ, Calvo SE, Chang B, Sheth SA, Vafai SB, Ong SE, Walford GA, Sugiana C, Boneh A, Chen WK, Hill DE, Vidal M, Evans JG, Thorburn DR, Carr SA and Mootha VK: A mitochondrial protein compendium elucidates complex I disease biology. Cell 134: 112-123, 2008.

13. de Bari L, Valenti D, Atlante A and Passarella S: L-lactate generates hydrogen peroxide in purified rat liver mitochondria due to the putative L-lactate oxidase localized in the intermembrane space. FEBS Lett 584: 2285-2290, 2010.

14. Pedersen P: Warburg, me and Hexokinase 2: Multiple discoveries of key molecular events underlying one of cancers' most common phenotypes, the 'Warburg Effect', i.e., elevated glycolysis in the presence of oxygen. J Bioenerg Biomembr 39: 211-222, 2007

15. Hochachka PW, Rupert JL, Goldenberg L, Gleave M and Kozlowski P: Going malignant: the hypoxia cancer connection in the prostate. Bioessays 24: 749-757, 2002.

16. Costello LC and Franklin RB: 'Why do tumour cells glycolyse?': From glycolysis through citrate to lipogenesis. Mol Cell Biochem 280: 1-8, 2005.

17. Matheson BK, Adams JL, Zou J, Patel R and Franklin RB: Effect of metabolic inhibitors on ATP and citrate content in PC3 prostate cancer cells. The Prostate 67: 1211-1218, 2007.

18. Liu Y: Fatty acid oxidation is a dominant bioenergetic pathway in prostate cancer. Prostate Cancer Prostatic Dis 3: 230-234, 2006.

19. Costello LC and Franklin RB: The intermediary metabolism of the prostate: a key to understanding the pathogenesis and progression of prostate malignancy. Oncology 59: 269-282, 2000 . 
20. Shannon JE: Tissue culture viability assays - a review of the literature. Cryobiology 15: 239-241, 1978.

21. Pallotti F and Lenaz G: Isolation and subfractionation of mitochondria from animal cells and tissue culture lines. Met Cell Bio 80: 3-44, 2007.

22. Atlante A, Gagliardi S, Marra E and Calissano P: Neuronal apoptosis in rats is accompanied by rapid impairment of cellular respiration and is prevented by scavengers of reactive oxygen species. Neurosci Lett 245: 127-130, 1998.

23. Lohr GW and Waller HD: Glucose-6-phosphate dehydrogenase. In: Methods of Enzymatic Analysis. Bergmeyer HU (ed). Verlag Chemie GmbH, Weinheim, pp744-751, 1963.

24. Harris DA: Spectrophotometric assays. In: Spectrophotometric and Spectrofluorimetry: a Pratical Approach. Bashford CL and Harris DA (eds). IRL Press, Oxford, pp59-61, 1987.

25. Atlante A, de Bari L, Bobba A, Marra E and Passarella S: Transport and metabolism of L-lactate occur in mitochondria from cerebellar granule cells and are modified in cells undergoing low potassium dependent apoptosis. Biochim Biophys Acta 1767: 1285-1299, 2007.

26. de Bari L, Atlante A, Valenti D and Passarella S: Partial reconstruction of in vitro gluconeogenesis arising from mitochondrial L-lactate uptake/metabolism and oxaloacetate export via novel L-lactate translocators. Biochem J 380: 231-242, 2004.

27. Laemmli UK: Cleavage of structural proteins during the assembly of the head of bacteriofage T4. Nature 227: 680-685, 1970.

28. Van Noorden CJ and Vogels IM: Cytophotometric analysis of reaction rates of succinate and lactate dehydrogenase activity in rat liver, heart muscle and tracheal epithelium. Histochem J 21: $575-583,1989$

29. Sjodin RA: Measurement of $\mathrm{Na}^{+}-\mathrm{K}^{+}$pump in muscle. Methods Enzymol 173: 695-714, 1989.

30. Liu Z, Shen J, Carbrey JM, Mukhopadhyay R, Agre P and Rosen BP: Arsenite transport by mammalian aquaglyceroporins AQP7 and AQP9. Proc Natl Acad Sci USA 99: 6053-6058, 2002.

31. Chappell JB and Haarhoff KN: The penetration of the mitochondrial membrane by anions and cations. In: Biochemistry of Mitochondria. Slater EC, Kaniuga Z and Wojtczak L (eds). Academic Press, London, pp75-91, 1966.
32. Passarella S, Atlante A, Valenti D and de Bari L: The role of mitochondria transport in energy metabolism. Mitochondrion 2: 319-343, 2003.

33. Valenti D, de Bari L, Atlante A and Passarella S: L-lactate transport into rat heart mitochondria and reconstruction of the L-lactate/pyruvate shuttle. Biochem J 364: 101-104, 2002.

34. Chowdhury SKR, Gemin A and Singh G: High activity of mitochondrial glycerophosphate dehydrogenase and glycerophosphate-dependent ROS production in prostate cancer cell lines. Biochem Biophys Res Comm 333: 1139-1145, 2005.

35. Costello LC, Guan Z, Kukoyi B, Feng P and Franklin RB: Terminal oxidation and the effects of zinc in prostate versus liver mitochondria. Mitochondrion 4: 331-338, 2004.

36. Putignani L, Raffa S, Pescosolido R, Aimati L, Signore F, Torrisi MR and Grammatico P: Alteration of expression levels of the oxidative phosphorylation system (OXPHOS) in breast cancer cell mitochondria. Breast Cancer Res Treat 110: 439-452, 2008.

37. Higgins LH, Withers HG, Garbens A, Love HD, Magnoni L, Hayward SW and Moyes CD: Hypoxia and the metabolic phenotype of prostate cancer cells. Biochim Biophys Acta 1787: 1433-1443, 2009

38. Halestrap AP and Price NT: The proton-linked monocarboxylate transporter (MCT) family: structure, function and regulation. Biochem J 343: 281-299, 1999.

39. Costello LC and Franklin RB: Prostate epithelial cells utilize glucose and aspartate as the carbon sources for net citrate production. Prostate 5: 335-342, 1989.

40. Toghrol F, Franklin RB and Costello LC: Citrate synthesis from fatty acids and amino acids in rat ventral prostate. Enzyme 25: 371-376, 1980

41. Sauer LA and Dauchy RT: Regulation of lactate production and utilization in rat tumors. J Biol Chem 260: 7496-7501, 1985.

42. Sonveaux P, Végran F, Schroeder T, Wergin MC, Verrax J, Rabbani ZN, De Saedeleer CJ, Kennedy KM, Diepart C, Jordan BF, Kelley MJ, Gallez B, Wahl ML, Feron O and Dewhirst MW: Targeting lactate-fuelled respiration selectively kills hypoxic tumor cells in mice. J Clin Invest 118: 3930-3942, 2008.

43. Tennant DA, Durán RV and Gottlieb E: Targeting metabolic transformation for cancer therapy. Nat Rev Cancer 10: 267-277, 2010. 